\title{
Gold(III) Salen Complex-Catalyzed Synthesis of Propargylamines via a Three-Component Coupling Reaction
}

\author{
Vanessa Kar-Yan Lo, Yungen Liu, Man-Kin Wong, * and Chi-Ming Che* \\ Department of Chemistry and Open Laboratory of Chemical Biology of the Institute of Molecular \\ Technology for Drug Discovery and Synthesis, The University of Hong Kong, Pokfulam Road, \\ Hong Kong, China
}

cmche@hku.hk, mkwong@hkusua.hku.hk

\section{Supporting Information}

\section{Table of Contents}

General Procedure for Synthesis of Gold(III) Salen Complexes 1a-e $\quad$ S2

General Procedure for Gold(III) Salen Complex-Catalyzed Three-component $\quad$ S2

Coupling Reaction

General Procedure for Synthesis of Artemisinin Derivatives 5-7 $\quad$ S2

$\begin{array}{ll}\text { Cytotoxicity Studies (MTT Assay) } & \text { S3 }\end{array}$

Literature References of 1a, 1c, [Au(TPP)Cl], (S)-Ethyl Prolinoate and Artemisinin S4

Aldehyde 4

Literature References of Propargylamines 2a-c, $2 \mathbf{f}$

S5

Characterization Data of Gold(III) Salen Complex 1b, 1d-e S6

Characterization Data pf Propargylamines 2d-e', 2g-i $\quad$ S7-9

Characterization Data of Artemisinin Derivatives 5-7 $\quad$ S10-13

${ }^{1}$ H NMR Spectra of Diastereomeric Mixtures of Propargylamines 2e-g, 2i $\quad$ S14-15

${ }^{1}$ H NMR Spectra of 1b, 1d-e, 2d-e', 2g-i, 5-7 S16-30

${ }^{13}$ C NMR Spectra of 2d-e', 2g-i, 5-7 $\quad$ S31-42 


\section{General Procedure for Synthesis of Gold(III) Salen Complexes 1a-e}

To a suspension of $\mathrm{KAuCl}_{4}(0.2 \mathrm{mmol})$ in $\mathrm{CH}_{2} \mathrm{Cl}_{2}(10 \mathrm{~mL})$ was added a solution of $\mathrm{NH}_{4} \mathrm{PF}_{6}(1.3$ $\mathrm{mmol})$ in $\mathrm{EtOH}(10 \mathrm{~mL})$. After dropwise addition of a solution of salen ligand $(1 \mathrm{mmol})$ in $\mathrm{CH}_{2} \mathrm{Cl}_{2}$ $(10 \mathrm{~mL})$, the reaction mixture was refluxed for $20 \mathrm{~min}$. After cooling, diethyl ether or hexane was added to the reaction mixture to induce precipitation. The precipitate was collected and washed with chloroform. The solid collected was then dissolved in $\mathrm{CH}_{3} \mathrm{CN}$ and filtered. The filtrate was concentrated under reduced pressure to give gold(III) salen complexes 1a-e.

\section{General Procedure for Gold(III) Salen Complex-Catalyzed Three-Component Coupling Reaction}

A mixture of $1 \mathbf{a}(0.02 \mathrm{mmol})$, aldehyde $(2.0 \mathrm{mmol})$, amine $(2.2 \mathrm{mmol})$ and alkyne $(3.0 \mathrm{mmol})$ in water $(1 \mathrm{~mL})$ were stirred at $40{ }^{\circ} \mathrm{C}$ for $24 \mathrm{~h}$ in the absence of light under $\mathrm{N}_{2}$ atmosphere. The reaction mixture was extracted with diethyl ether $(3 \times 15 \mathrm{~mL})$. The combined organic layers were dried over anhydrous $\mathrm{Na}_{2} \mathrm{SO}_{4}$, filtered, and concentrated under reduced pressure. The product was purified by flash column chromatography on silica gel using ethyl acetate-hexane as eluent.

\section{General Procedure for Synthesis of Artemisinin Derivatives 5-7}

A mixture of 1a $(0.005 \mathrm{mmol})$, aldehyde $4(0.1 \mathrm{mmol})$, amine $(0.22 \mathrm{mmol})$ and alkyne $(0.3 \mathrm{mmol})$ in water $(1 \mathrm{~mL})$ were stirred at $40{ }^{\circ} \mathrm{C}$ for $24 \mathrm{~h}$ in the absence of light under $\mathrm{N}_{2}$ atmosphere. The reaction mixture was extracted with diethyl ether $(3 \times 15 \mathrm{~mL})$. The combined organic layers were dried over anhydrous $\mathrm{Na}_{2} \mathrm{SO}_{4}$, filtered, and concentrated under reduced pressure. The product was purified by flash column chromatography on silica gel using ethyl acetate-hexane as eluent. 


\section{Cytotoxicity Studies (MTT Assay)}

Human hepatocellular carcinoma (HepG2) was maintained in a minimum essential medium with Earle's balanced salts (MEM). All the media were supplemented with $2 \mathrm{mM} \mathrm{L}$-glutamine and $10 \%$ fetal boviene serum. Penicillin $(100 \mathrm{U} / \mathrm{mL})$ and Streptomycin $(100 \mu \mathrm{g} / \mathrm{mL})$ were added to all media. Cultures were incubated at $37{ }^{\circ} \mathrm{C}$ in a $5 \% \mathrm{CO}_{2} / 95 \%$ air humidified atmosphere.

Assays on the cytotoxic effects were conducted in 96-well flat-bottomed microtitre plates. The supplemented culture medium $(100 \mu \mathrm{L})$ with cells $\left(4 \times 10^{4}\right.$ cells $\left./ \mathrm{mL}\right)$ was added into each well and was incubated $\left(37{ }^{\circ} \mathrm{C}, 5 \% \mathrm{CO}_{2} / 95 \%\right.$ air) for $24 \mathrm{~h}$. All the media were then removed and fresh supplemented medium (100 $\mu \mathrm{L}$ ) was added into each well. Compounds 5-7 dissolved in the culture medium (100 $\mu \mathrm{L}+<1 \%$ ethanol) were added into a set of wells. After mixing, the samplecontaining media $(100 \mu \mathrm{L})$ were drawn and added to another set of wells. Such processes were repeated to provide a set of two-fold dilution series. Controlled wells only contained $100 \mu \mathrm{L}$ of supplemented media. Microtitre plates were incubated at $37{ }^{\circ} \mathrm{C}$ in a $5 \% \mathrm{CO}_{2} / 95 \%$ air humidified atmosphere for further 6 days. All the cytotoxicity assays were run in parallel with a negative control (i.e., untreated population). Assessment of the cytotoxicity was carried out using a modified method of Mosmann based 3-(4, 5-Dimethylthiazol-2-yl)-2, 5-diphenyltetrazolium bromide (MTT) Assay [Mosmann, T. J. Immunol. Methods 1983, 65, 55 - 63.]. At the end of each incubation period, $10 \mu \mathrm{L}$ of the MTT solution (Cell Proliferation Kit I, Roche) were added into each well and the cultures were further incubated for $4 \mathrm{~h}$ at $37{ }^{\circ} \mathrm{C}$ in a $5 \% \mathrm{CO}_{2} / 95 \%$ air humidified atmosphere. Then $100 \mu \mathrm{L}$ of the solubilization solution was added into the wells to lyse the cells and solubilize the formazan complex formed. The microtitre plates were maintained in a dark and humidified chamber overnight. The formation of formazan was measured with a microtitre plate reader at $550 \mathrm{~nm}$, and the percentages of cell survival were determined. The cytotoxicity was evaluated based on the percentage cell survival in a dose-dependence manner relative to the negative control. 
Literature References of 1a, 1c, [Au(TPP)Cl], (S)-Ethyl Prolinoate and Artemisinin Aldehyde 4

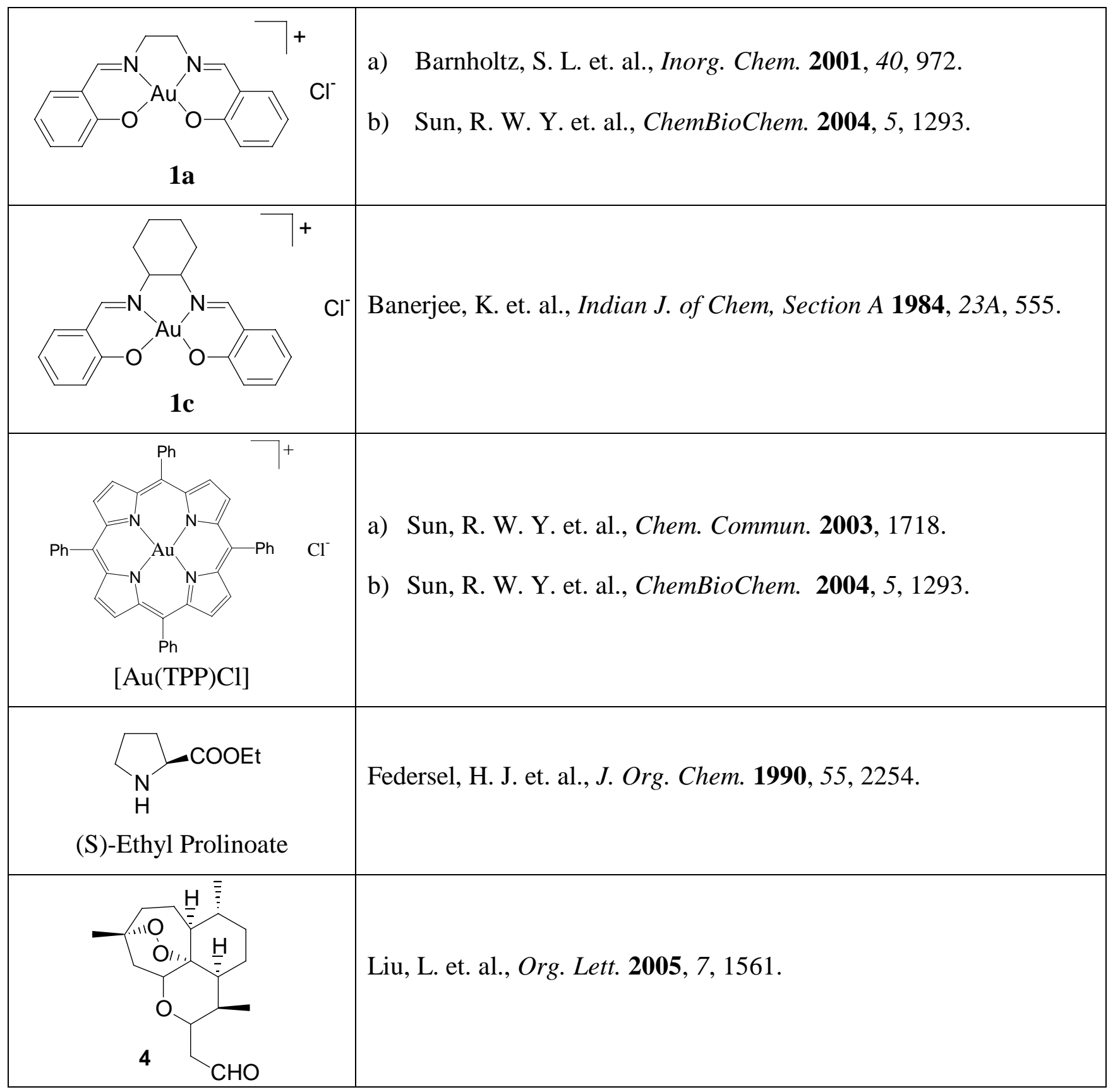


Literature References of Propargylamines 2a-c, 2f

\begin{tabular}{|l|l|}
\hline & a) Wei, C. et. al., J. Am. Chem. Soc. 2003, 125, 9584. \\
b) Wei. C. et. al., Org. Lett. 2003, 5, 4473. \\
c) Shi, L. et. al., Org. Lett. 2004, 6, 1001.
\end{tabular}




\section{Characterization Data of Gold(III) Salen Complex 1b, 1d-e}

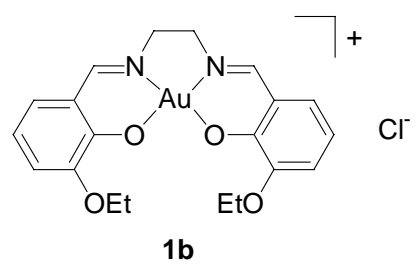

Brownish yellow solid; ${ }^{1} \mathrm{H}$ NMR (300 MHz, $\left.\mathrm{CD}_{3} \mathrm{CN}\right) \delta 8.45(\mathrm{~s}, 2 \mathrm{H}), 6.99-6.92(\mathrm{~m}, 4 \mathrm{H}), 6.79-6.71(\mathrm{t}$, $\mathrm{J}=7.9 \mathrm{~Hz}, 2 \mathrm{H}), 4.10-4.03(\mathrm{q}, \mathrm{J}=7.0 \mathrm{~Hz}, 4 \mathrm{H}), 3.93(\mathrm{~s}, 4 \mathrm{H}), 1.41-1.36(\mathrm{t}, \mathrm{J}=7.0 \mathrm{~Hz}, 6 \mathrm{H}) ; \mathrm{IR}(\mathrm{KBr}$, $\left.\mathrm{cm}^{-1}\right)$ 1633, 1496, 1454; FAB-MS m/z $551\left(\mathrm{M}^{+}\right)$.

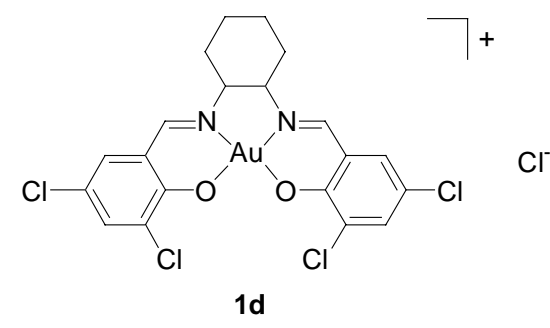

Orange solid; ${ }^{1} \mathrm{H}$ NMR (300 MHz, $\left.\mathrm{CD}_{3} \mathrm{CN}\right) \delta 8.35(\mathrm{~s}, 2 \mathrm{H}), 7.94-7.93(\mathrm{~d}, J=2.6 \mathrm{~Hz}, 2 \mathrm{H}), 7.81-7.80$ $(\mathrm{d}, J=2.6 \mathrm{~Hz}, 2 \mathrm{H}), 4.07-4.05(\mathrm{~m}, 2 \mathrm{H}), 2.83-2.79(\mathrm{~m}, 2 \mathrm{H}), 1.88-1.86(\mathrm{~m}, 2 \mathrm{H}), 1.60-1.45(\mathrm{~m}, 2 \mathrm{H}) ; \mathrm{IR}$ $\left(\mathrm{KBr}, \mathrm{cm}^{-1}\right) 1628,1593,1435,1321$; FAB-MS $m / z 655\left(\mathrm{M}^{+}\right)$.

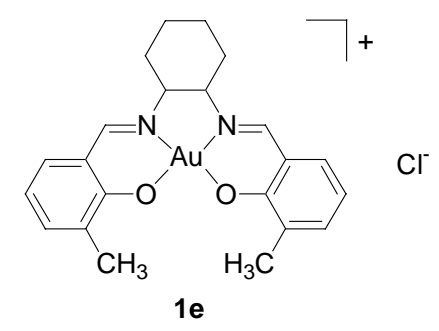

Orange solid, ${ }^{1} \mathrm{H}$ NMR $\left(300 \mathrm{MHz}, \mathrm{CD}_{3} \mathrm{CN}\right) \delta 8.36(\mathrm{~s}, 2 \mathrm{H}), 7.65-7.62(\mathrm{~m}, 4 \mathrm{H}), 6.97-6.92(\mathrm{t}, J=7.5$ Hz, 2H), 3.99-3.96 (m, 2H), 2.84-2.80 (d, $J=11.7 \mathrm{~Hz}, 2 \mathrm{H}), 2.38(\mathrm{~s}, 6 \mathrm{H}), 1.90-1.80$ (m, 2H), 1.53$1.47(\mathrm{t}, J=9.9 \mathrm{~Hz}, 2 \mathrm{H})$; IR $\left(\mathrm{KBr}, \mathrm{cm}^{-1}\right) 1602,1552,1313 ; \mathrm{FAB}-\mathrm{MS} m / z, 545\left(\mathrm{M}^{+}\right)$. 


\section{Characterization Data of Propargylamines 2d - 2e, 2g - 2i}

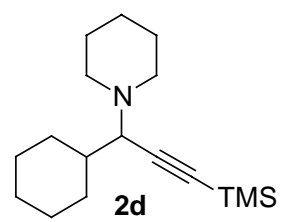

Colorless oil; analytical TLC (silica gel 60) (10\% EtOAc in hexane), $\mathrm{R}_{f}=0.51 ;{ }^{1} \mathrm{H} \mathrm{NMR}(300 \mathrm{MHz}$, $\left.\mathrm{CDCl}_{3}\right) \delta 2.89-2.86(\mathrm{~d}, J=10.0 \mathrm{~Hz}, 1 \mathrm{H}), 2.55-2.47(\mathrm{~m}, 2 \mathrm{H}), 2.30-2.26(\mathrm{~m}, 2 \mathrm{H}), 2.03-1.94(\mathrm{~m}, 2 \mathrm{H})$, $1.75-1.39(\mathrm{~m}, 11 \mathrm{H}), 1.23-1.14(\mathrm{~m}, 2 \mathrm{H}), 1.00-0.84(\mathrm{~m}, 2 \mathrm{H}), 0.18(\mathrm{~s}, 9 \mathrm{H}) ;{ }^{13} \mathrm{C} \mathrm{NMR}(125 \mathrm{MHz}$ $\left.\mathrm{CDCl}_{3}\right) \delta 104.12,89.77,64.59,50.55,39.30,31.15,30.37,29.72,26.82,26.27,26.24,26.10,24.74$, 0.42; IR (KBr, neat, $\mathrm{cm}^{-1}$ ) 2158; EIMS m/z $277\left(\mathrm{M}^{+}\right)$; HRMS (EI) for $\mathrm{C}_{17} \mathrm{H}_{31} \mathrm{NSi}$, calcd 277.2226, found 277.2221 .

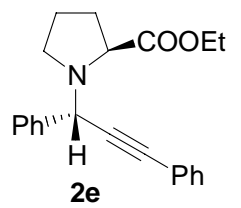

Yellow oil; analytical TLC (silica gel 60) (10\% EtOAc in hexane), $\mathrm{R}_{f}=0.29 ;{ }^{1} \mathrm{H}$ NMR $(300 \mathrm{MHz}$, $\left.\mathrm{CDCl}_{3}\right) \delta 7.70-7.68(\mathrm{~d}, J=7.4 \mathrm{~Hz}, 2 \mathrm{H}), 7.53-7.50(\mathrm{~m}, 2 \mathrm{H}), 7.38-7.25(\mathrm{~m}, 6 \mathrm{H}), 5.27(\mathrm{~s}, 1 \mathrm{H}), 4.32-$ $4.18(\mathrm{~m}, 2 \mathrm{H}), 3.78-3.73(\mathrm{dd}, J=9.0,6.9 \mathrm{~Hz}, 1 \mathrm{H}), 2.79-2.66(\mathrm{~m}, 2 \mathrm{H}), 2.25-1.99(\mathrm{~m}, 2 \mathrm{H}), 1.82-1.74$ $(\mathrm{m}, 2 \mathrm{H}), 1.34-1.29(\mathrm{t}, J=7.1 \mathrm{~Hz}, 3 \mathrm{H}) ;{ }^{13} \mathrm{C} \mathrm{NMR}\left(125 \mathrm{MHz}, \mathrm{CDCl}_{3}\right) \delta 174.10,139.11,131.88$, $128.36,128.32,128.29,128.24,127.59,123.06,87.98,85.32,63.25,60.72,57.30,47.37,29.33$, 23.24, 14.37; IR (KBr, neat, $\left.\mathrm{cm}^{-1}\right)$ 2361, 1741; EIMS m/z $333\left(\mathrm{M}^{+}\right)$; HRMS (EI) for $\mathrm{C}_{22} \mathrm{H}_{23} \mathrm{NO}_{2}$, calcd 333.1729, found 333.1742. 


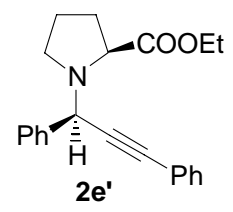

Yellow oil; analytical TLC (silica gel 60) (10\% EtOAc in hexane), $\mathrm{R}_{f}=0.15 ;{ }^{1} \mathrm{H}$ NMR $(300 \mathrm{MHz}$, $\left.\mathrm{CDCl}_{3}\right) \delta 7.60-7.58(\mathrm{~d}, J=7.2 \mathrm{~Hz}, 2 \mathrm{H}), 7.51-7.48(\mathrm{~m}, 2 \mathrm{H}), 7.35-7.27(\mathrm{~m}, 6 \mathrm{H}), 5.12(\mathrm{~s}, 1 \mathrm{H}), 3.82-$ $3.74(\mathrm{q}, J=7.1 \mathrm{~Hz}, 2 \mathrm{H}), 3.61-3.57(\mathrm{dd}, J=9.3,4.5 \mathrm{~Hz}, 1 \mathrm{H}), 3.34-3.30(\mathrm{td}, J=8.4,2.7 \mathrm{~Hz}, 1 \mathrm{H})$, 3.04-2.96 (m, 1H), 2.16-1.91 (m, 2H), 1.89-1.83 (m, 2H), 1.05-1.01 (t, $J=7.1 \mathrm{~Hz}, 3 \mathrm{H}) ;{ }^{13} \mathrm{C}$ NMR $\left(125 \mathrm{MHz}, \mathrm{CDCl}_{3}\right) \delta 174.75,138.14,131.86,128.87,128.44,128.36,128.35,128.31,128.28$, $128.14,127.88,122.98,87.12,86.37,60.85,60.31,58.54,53.03,30.89,29.71,24.07,14.12$; IR $\left(\mathrm{KBr}\right.$, neat, $\left.\mathrm{cm}^{-1}\right)$ 2361, 1741; EIMS m/z $333\left(\mathrm{M}^{+}\right)$; HRMS (EI) for $\mathrm{C}_{22} \mathrm{H}_{23} \mathrm{NO}_{2}$, calcd 333.1729, found 333.1742 .

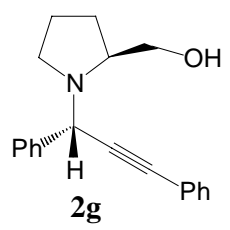

Pale yellow oil; analytical TLC (silica gel 60) (30\% EtOAc in hexane), $\mathrm{R}_{f}=0.24 ;{ }^{1} \mathrm{H}$ NMR (300 $\left.\mathrm{MHz} \mathrm{CDCl}_{3}\right) \delta$ 7.61-7.59 (d, J=7.2 Hz, 2H), 7.53-7.48 (m, 2H), 7.40-7.30 (m, 6H), $5.12(\mathrm{~s}, 1 \mathrm{H})$, 3.86-3.81 (dd, $J=10.9,3.5 \mathrm{~Hz}, 1 \mathrm{H}), 3.56-3.51(\mathrm{dd}, J=10.9,2.2 \mathrm{~Hz}, 1 \mathrm{H}), 3.31-3.27(\mathrm{~m}, 1 \mathrm{H}), 2.86-$ $2.77(\mathrm{dd}, J=9.2,7.3 \mathrm{~Hz}, 1 \mathrm{H}), 2.66-2.59(\mathrm{td}, J=8.0,3.0 \mathrm{~Hz}, 1 \mathrm{H}), 1.97-1.92(\mathrm{~m}, 1 \mathrm{H}), 1.87-1.75(\mathrm{~m}$, 1H), 1.73-1.66 (m, 2H); ${ }^{13} \mathrm{C}$ NMR (125 MHz, $\left.\mathrm{CDCl}_{3}\right) \delta 139.18,131.85,128.46,128.40,128.37$, $128.34,128.31,128.09,127.62,122.99,87.83,85.37,61.83,61.75,56.25,47.90,28.04,23.60 ;$ IR $\left(\mathrm{KBr}\right.$, neat, $\left.\mathrm{cm}^{-1}\right)$ 3436, 2361, 2341; EIMS m/z $291\left(\mathrm{M}^{+}\right)$; HRMS (EI) for $\mathrm{C}_{20} \mathrm{H}_{21} \mathrm{NO}$, calcd 291.1623, found 291.1617. 


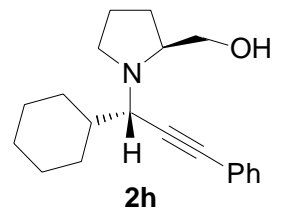

Yellow oil; analytical TLC (silica gel 60) (30\% EtOAc in hexane), $\mathrm{R}_{f}=0.56 ;{ }^{1} \mathrm{H}$ NMR (400 MHz, $\left.\mathrm{CDCl}_{3}\right) \delta$ 7.43-7.40 (m, 2H), 7.30-7.28 (m, 3H), 3.68-3.63 (dd, $\left.J=10.9,3.4 \mathrm{~Hz}, 1 \mathrm{H}\right), 3.42-3.38(\mathrm{dd}$, $J=10.8,3.0 \mathrm{~Hz}, 2 \mathrm{H}), 3.13-3.08(\mathrm{~m}, 1 \mathrm{H}), 2.91-2.81(\mathrm{~m}, 2 \mathrm{H}), 2.16-2.05(\mathrm{~m}, 2 \mathrm{H}), 1.92-1.51(\mathrm{~m}, 8 \mathrm{H})$, 1.36-1.87 (m, 4H), 1.08-0.87 (m, 2H); ${ }^{13} \mathrm{C}$ NMR (125 MHz, $\left.\mathrm{CDCl}_{3}\right) \delta 131.74,128.09,127.95$, $123.33,87.23,86.00,61.97,61.26,56.59,47.18,41.21,31.43,30.29,27.78,26.60,26.08,25.94$, 23.98; IR (KBr, neat, $\left.\mathrm{cm}^{-1}\right) 3449,2361$; EIMS m/z $266\left(\mathrm{M}^{+}-\mathrm{CH}_{2} \mathrm{OH}\right)$; HRMS (EI) for $\mathrm{C}_{19} \mathrm{H}_{24} \mathrm{~N}$, calcd 266.1909, found 266.1908.

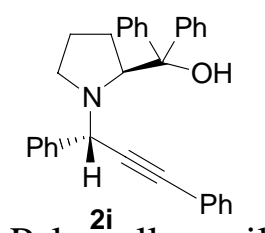

Pale yellow oil; analytical TLC (silica gel 60) (10\% EtOAc in hexane), $\mathrm{R}_{f}=0.39 ;{ }^{1} \mathrm{H}$ NMR (300 $\left.\mathrm{MHz}, \mathrm{CDCl}_{3}\right) \delta$ 7.86-7.83 (dd, $\left.J=8.4,1.2 \mathrm{~Hz}, 2 \mathrm{H}\right), 7.64-7.61(\mathrm{dd}, J=8.3,1.2 \mathrm{~Hz}, 2 \mathrm{H}), 7.57-7.54$ (m, 2H), 7.40-7.37 (m, 3H), 7.32-7.29 (m, 6H), 7.26-7.21 (m, 3H), 7.20-7.12 (m, 2H), $4.69(\mathrm{~s}, 1 \mathrm{H})$, $4.52-4.49(\mathrm{q}, J=5.0 \mathrm{~Hz}, 1 \mathrm{H}), 4.27(\mathrm{~s}, 1 \mathrm{H}), 2.98-2.89(\mathrm{td}, J=9.1,7.1 \mathrm{~Hz}, 1 \mathrm{H}), 1.98-1.82(\mathrm{~m}, 1 \mathrm{H})$, 1.81-1.60 (m, 3H); ${ }^{13} \mathrm{C}$ NMR (125 MHz, $\left.\mathrm{CDCl}_{3}\right) \delta 147.98,146.53,139.19,131.89,128.74,128.43$, $128.40,128.32,128.12,128.11,127.99,127.90,127.44,127.02,126.68,126.28,125.49,125.46$, $123.16,87.58,85.83,77.89,68.10,57.90,49.48 .30 .92,29.89,24.26$; IR (KBr, neat, $\left.\mathrm{cm}^{-1}\right) 3391$, 2360; FAB-MS m/z $444\left(\mathrm{M}^{+}+\mathrm{H}\right)$ 


\section{Characterization Data of Artemisinin Derivatives 5-7}

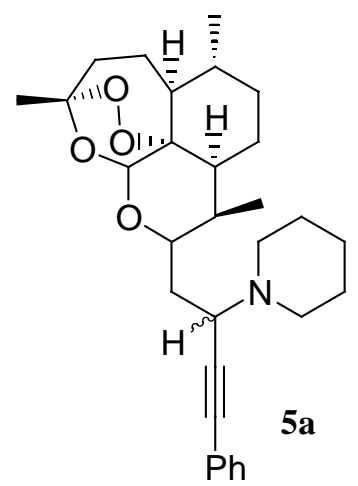

Pale yellow oil; analytical TLC (silica gel 60) (40\% EtOAc in hexane), $\mathrm{R}_{f}=0.34 ;{ }^{1} \mathrm{H}$ NMR (300 $\left.\mathrm{MHz}, \mathrm{CDCl}_{3}\right) \delta$ 7.44-7.41 (m, 2H), 7.32-7.28 (m, 3H), $5.23(\mathrm{~s}, 1 \mathrm{H}), 4.04-3.99(\mathrm{dd}, J=10.9,3.8 \mathrm{~Hz}$, $1 \mathrm{H}), 3.71-3.63(\mathrm{td}, J=10.1,2.1 \mathrm{~Hz}, 1 \mathrm{H}), 2.71-2.64(\mathrm{~m}, 2 \mathrm{H}), 2.59-2.56(\mathrm{~m}, 2 \mathrm{H}), 2.37-2.30(\mathrm{~m}, 2 \mathrm{H})$, 2.03-1.92 (m, 2H), 1.89-1.84 (m, 2H), 1.69-1.20 (m, 13H), $1.40(\mathrm{~s}, 3 \mathrm{H}), 0.95-0.93(\mathrm{~d}, J=6.2 \mathrm{~Hz}$, $3 \mathrm{H}), 0.83-0.81(\mathrm{~d}, J=7.1 \mathrm{~Hz}, 3 \mathrm{H}), 1.09-0.85(\mathrm{~m}, 1 \mathrm{H}) ;{ }^{13} \mathrm{C}$ NMR $\left(125 \mathrm{MHz}, \mathrm{CDCl}_{3}\right) \delta 131.76$, $128.22,127.76,123.72,103.99,92.11,88.09,85.92,80.78,71.85,54.84,52.07,50.73,46.36,37.32$, $37.10,36.42,34.22,32.32,30.36,29.71,26.20,26.01,24.81,24.56,21.48,20.33,14.10$; IR (KBr, neat, $\mathrm{cm}^{-1}$ ) 2361; EIMS m/z $479\left(\mathrm{M}^{+}\right)$; HRMS (EI) for $\mathrm{C}_{30} \mathrm{H}_{41} \mathrm{NO}_{4}$, calcd 479.3036, found 479.3046.

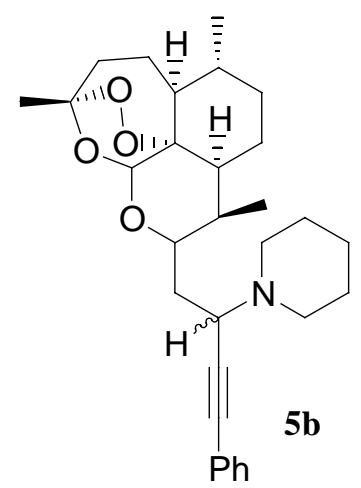

Pale yellow oil; analytical TLC (silica gel 60) (40\% EA in hexane), $\mathrm{R}_{f}=0.48 ;{ }^{1} \mathrm{H} \mathrm{NMR}(300 \mathrm{MHz}$, $\left.\mathrm{CDCl}_{3}\right) \delta 7.44-7.41(\mathrm{~m}, 2 \mathrm{H}), 7.28-7.26(\mathrm{~m}, 3 \mathrm{H}), 5.24(\mathrm{~s}, 1 \mathrm{H}), 3.97-3.92(\mathrm{dd}, J=9.3,5.0 \mathrm{~Hz}, 1 \mathrm{H})$, 3.76-3.69 (td, J = 10.1, 2.1 Hz, 1H), 2.62-2.58 (m, 2H), 2.48-2.35 (m, 4H), 2.06-1.98 (m, 2H), 1.90$1.71(\mathrm{~m}, 2 \mathrm{H}), 1.69-1.08(\mathrm{~m}, 13 \mathrm{H}), 1.41(\mathrm{~s}, 3 \mathrm{H}), 0.97-0.95(\mathrm{~d}, J=6.3 \mathrm{~Hz}, 3 \mathrm{H}), 0.84-0.81(\mathrm{~d}, J=7.1$ 
$\mathrm{Hz}, 3 \mathrm{H}), 1.07-0.88(\mathrm{~m}, 1 \mathrm{H}) ;{ }^{13} \mathrm{C} \mathrm{NMR}\left(125 \mathrm{MHz}, \mathrm{CDCl}_{3}\right) \delta 131.71,128.16,127.62,103.94,92.11$, $80.92,70.95,53.68,52.09,50.32,46.41,37.35,36.43,34.27,36.43,34.27,31.93,31.76,30.33$, $29.94,29.71,29.37,26.30,26.15,24.83,24.67,22.70,21.45,20.34,14.12,14.04 ; \mathrm{IR}\left(\mathrm{KBr}\right.$, neat, $\mathrm{cm}^{-}$ ${ }^{1}$ ) 2360; EIMS $m / z 479\left(\mathrm{M}^{+}\right)$; HRMS (EI) for $\mathrm{C}_{30} \mathrm{H}_{41} \mathrm{NO}_{4}$, calcd 479.3036, found 479.3056.

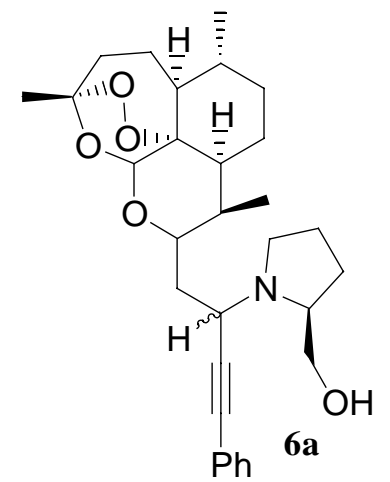

Pale yellow oil; analytical TLC (silica gel 60) (50\% EA in hexane), $\mathrm{R}_{f}=0.32 ;{ }^{1} \mathrm{H}$ NMR (400 MHz, $\left.\mathrm{CDCl}_{3}\right) \delta$ 7.42-7.39 (m, 2H), 7.30-7.28 (m, 3H), $5.23(\mathrm{~s}, 1 \mathrm{H}), 4.36-4.33(\mathrm{dd}, J=10.6,5.0 \mathrm{~Hz}, 1 \mathrm{H})$, 3.69-3.63 (td, $J=11.0,3.4 \mathrm{~Hz}, 2 \mathrm{H}), 3.39-3.35(\mathrm{dd}, J=11.0,5.3 \mathrm{~Hz}, 1 \mathrm{H}), 3.14-3.08$ (m, 1H), 2.94$2.84(\mathrm{~m}, 2 \mathrm{H}), 2.38-2.26(\mathrm{~m}, 3 \mathrm{H}), 2.03-1.73(\mathrm{~m}, 6 \mathrm{H}), 1.72-1.61(\mathrm{~m}, 3 \mathrm{H}), 1.55-1.51(\mathrm{~m}, 2 \mathrm{H}), 1.49-1.44$ $(\mathrm{m}, 1 \mathrm{H}), 1.42(\mathrm{~s}, 3 \mathrm{H}), 1.40-1.32(\mathrm{~m}, 1 \mathrm{H}), 1.27-1.21(\mathrm{~m}, 2 \mathrm{H}), 1.04-0.97(\mathrm{~m}, 1 \mathrm{H}), 0.95-0.94(\mathrm{~d}, J=6.3$ $\mathrm{Hz}, 3 \mathrm{H}), 0.83-0.81(\mathrm{~d}, J=7.1 \mathrm{~Hz}, 3 \mathrm{H}) ;{ }^{13} \mathrm{C} \mathrm{NMR}\left(125 \mathrm{MHz}, \mathrm{CDCl}_{3}\right) \delta 131.71,128.22,127.82$, $123.43,104.14,92.21,88.65,84.61,80.84,70.30,64.36,62.14,52.04,48.99,47.27,46.17,37.81$, $37.22,36.29,34.17,32.46,27.72,26.04,24.67,24.24,21.54,20.30,13.75$; IR (KBr, neat, $\left.\mathrm{cm}^{-1}\right)$ 3468, 2361, 2341, 2245, 1641; EIMS m/z $495\left(\mathrm{M}^{+}\right)$; HRMS (EI) for $\mathrm{C}_{30} \mathrm{H}_{41} \mathrm{NO}_{5}$, calcd 495.2985, found 495.2990. 


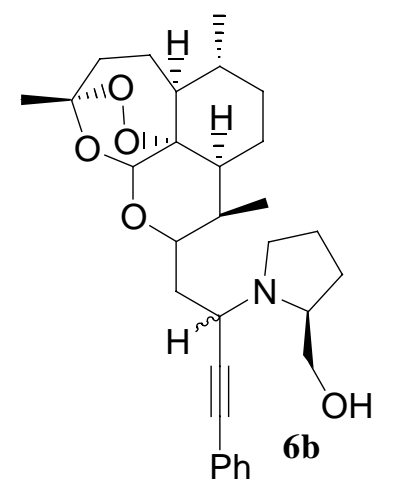

Pale yellow oil; analytical TLC (silica gel 60) (50\% EA in hexane), $\mathrm{R}_{f}=0.05 ;{ }^{1} \mathrm{H}$ NMR $(300 \mathrm{MHz}$, $\left.\mathrm{CDCl}_{3}\right) \delta$ 7.42-7.39 (m, 2H), 7.32-7.29 (m, 3H), 4.24-4.19 (m, 1H), 3.72-3.63 (m, 1H), 3.58-3.53 (dd, $J=10.4,4.36 \mathrm{~Hz}, 1 \mathrm{H}), 3.40-3.29(\mathrm{~m}, 2 \mathrm{H}), 3.19-3.13(\mathrm{~m}, 1 \mathrm{H}), 2.96-2.88(\mathrm{~m}, 1 \mathrm{H}), 2.42-2.27(\mathrm{~m}$, $2 \mathrm{H}), 2.04-1.21(\mathrm{~m}, 18 \mathrm{H}), 1.42(\mathrm{~s}, 3 \mathrm{H}), 0.96-0.94(\mathrm{~d}, J=6.18 \mathrm{~Hz}, 3 \mathrm{H}), 0.83-0.81(\mathrm{~d}, J=7.16 \mathrm{~Hz}, 3 \mathrm{H})$, 1.07-0.86 (m, 1H); ${ }^{13} \mathrm{C}$ NMR $\left(75 \mathrm{MHz}, \mathrm{CDCl}_{3}\right) \delta 131.71,128.31,127.97,123.45,104.08,92.27$, $89.27,80.88,77.46,72.02,65.38,59.73,54.16,52.52,52.11,46.29,38.76,37.35,36.41,34.20$, 32.46, 30.12, 29.72, 26.07, 24.77, 21.55, 20.33, 14.07; IR (KBr, neat, $\left.\mathrm{cm}^{-1}\right) 3437,2360,2341$; EIMS $m / 2464\left(\mathrm{M}-\mathrm{CH}_{2} \mathrm{OH}\right)$.

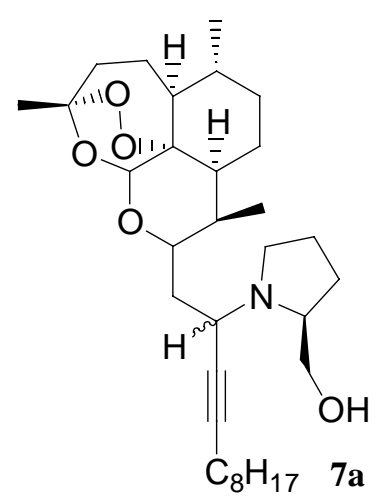

Colorless oil; analytical TLC (silica gel 60) (50\% EA in hexane), $\mathrm{R}_{f}=0.40 ;{ }^{1} \mathrm{H}$ NMR (400 MHz, $\left.\mathrm{CDCl}_{3}\right) \delta 5.20(\mathrm{~s}, 1 \mathrm{H}), 4.10-4.05(\mathrm{~m}, 1 \mathrm{H}), 3.64-3.56(\mathrm{~m}, 2 \mathrm{H}), 3.34-3.30(\mathrm{dd}, J=10.9,5.1 \mathrm{~Hz}, 1 \mathrm{H})$, 3.03-2.97 (m, 1H), 2.82-2.74 (m, 2H), 2.37-2.26 (m, 2H), 2.20-2.16 (td, $J=6.9,1.9 \mathrm{~Hz}, 2 \mathrm{H}), 2.02-$ $1.96(\mathrm{~m}, 1 \mathrm{H}), 1.87-1.55(\mathrm{~m}, 1 \mathrm{H}), 1.52-1.45(\mathrm{~m}, 10 \mathrm{H}), 1.44(\mathrm{~s}, 3 \mathrm{H}), 1.38-1.32(\mathrm{~m}, 2 \mathrm{H}), 1.28-1.18(\mathrm{~m}$, $11 \mathrm{H}), 1.06-0.99$ (td, $J=12.5,3.3 \mathrm{~Hz}, 1 \mathrm{H}), 0.94-0.93(\mathrm{~d}, J=6.3 \mathrm{~Hz}, 3 \mathrm{H}), 0.90-0.87$ (t, $J=6.9 \mathrm{~Hz}$, 
3H), 0.79-0.78 (d, $J=7.2 \mathrm{~Hz}, 3 \mathrm{H}) ;{ }^{13} \mathrm{C}$ NMR $\left(125 \mathrm{MHz}, \mathrm{CDCl}_{3}\right) \delta 104.08,92.17,84.52,80.85$, $78.55,70.34,64.15,61.88,52.07,48.37,46.93,46.21,38.16,37.21,36.31,34.20,32.42,31.84$, $29.24,29.13,29.10,28.81,27.72,26.04,24.67,24.16,22.66,21.54,20.29,18.63,14.10,13.74$; IR $\left(\mathrm{KBr}\right.$, neat, $\left.\mathrm{cm}^{-1}\right)$ 3452, 2361, 1641; EIMS m/z $500\left(\mathrm{M}^{+}-\mathrm{CH}_{2} \mathrm{OH}\right)$; HRMS (EI) for $\mathrm{C}_{31} \mathrm{H}_{49} \mathrm{NO}_{4}$, calcd 500.3740, found 500.3752 .

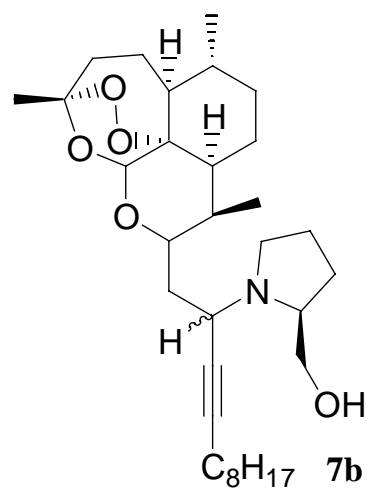

Colorless oil; analytical TLC (silica gel 60) (50\% EA in hexane) $\mathrm{R}_{f}=0.10 ;{ }^{1} \mathrm{H}$ NMR $\delta 5.20(\mathrm{~s}, 1 \mathrm{H})$, 3.98-3.93 (m, 1H), 3.64-3.57 (td, $J=9.7,2.3 \mathrm{~Hz}, 1 \mathrm{H}), 3.54-3.49$ (m, 1H), 3.36-3.31 (dd, $J=10.5$, $3.5 \mathrm{~Hz}, 1 \mathrm{H}), 2.23-3.19(\mathrm{~m}, 1 \mathrm{H}), 3.08-3.04(\mathrm{~m}, 1 \mathrm{H}), 2.86-2.77(\mathrm{~m}, 2 \mathrm{H}), 2.31-2.25(\mathrm{~m}, 2 \mathrm{H}), 2.22-2.17$ (m, 2H), 2.05-1.67 (m, 10H), 1.50-1.47 (m, 4H), $1.46(\mathrm{~s}, 3 \mathrm{H}), 1.33-1.21(\mathrm{~m}, 10 \mathrm{H}), 1.09-1.00(\mathrm{~m}$, $1 \mathrm{H}), 0.96-0.94(\mathrm{~d}, J=6.2 \mathrm{~Hz}, 3 \mathrm{H}), 0.90-0.86(\mathrm{t}, J=6.5 \mathrm{~Hz}, 3 \mathrm{H}), 0.80-0.78(\mathrm{~d}, J=7.2 \mathrm{~Hz}, 3 \mathrm{H}) ;{ }^{13} \mathrm{C}$ NMR (125 MHz, $\left.\mathrm{CDCl}_{3}\right) \delta 103.99,92.21,84.77,80.87,72.00,65.34,59.34,52.08,46.28,38.75$, $37.36,36.38,34.21,32.34,31.93,30.20,29.70,29.25,29.11,28.86,26.06,24.69,22.69,21.54$, 22.69, 21.54, 20.33, 18.70, 14.11; IR (KBr, neat, $\left.\mathrm{cm}^{-1}\right)$ 3439, 2352; EIMS m/z $531\left(\mathrm{M}^{+}\right)$. 


\section{${ }^{1} \mathrm{H}$ NMR Spectra of Diastereomeric Mixtures of 2e-g, 2i}

Table 2, entry 5

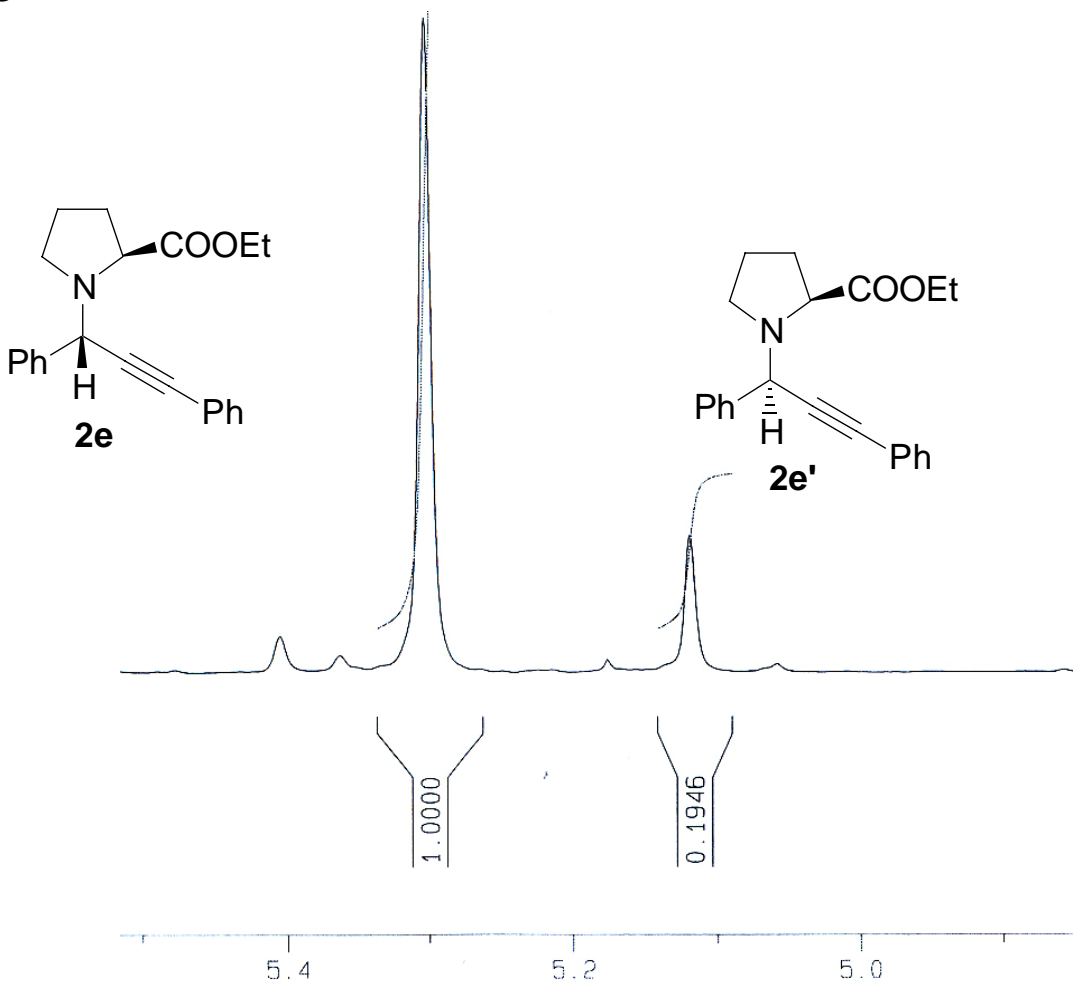

Table 2, entry 6

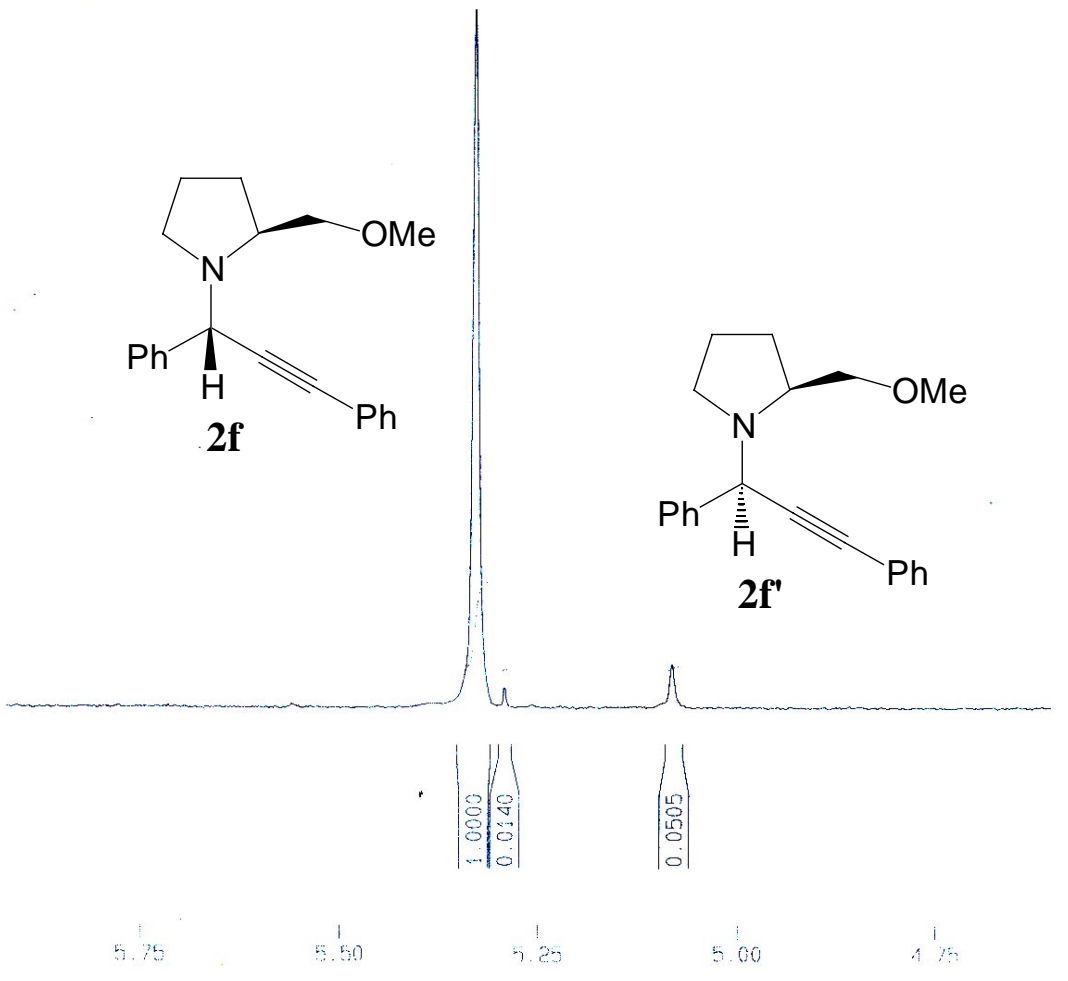


Table 2, entry 7

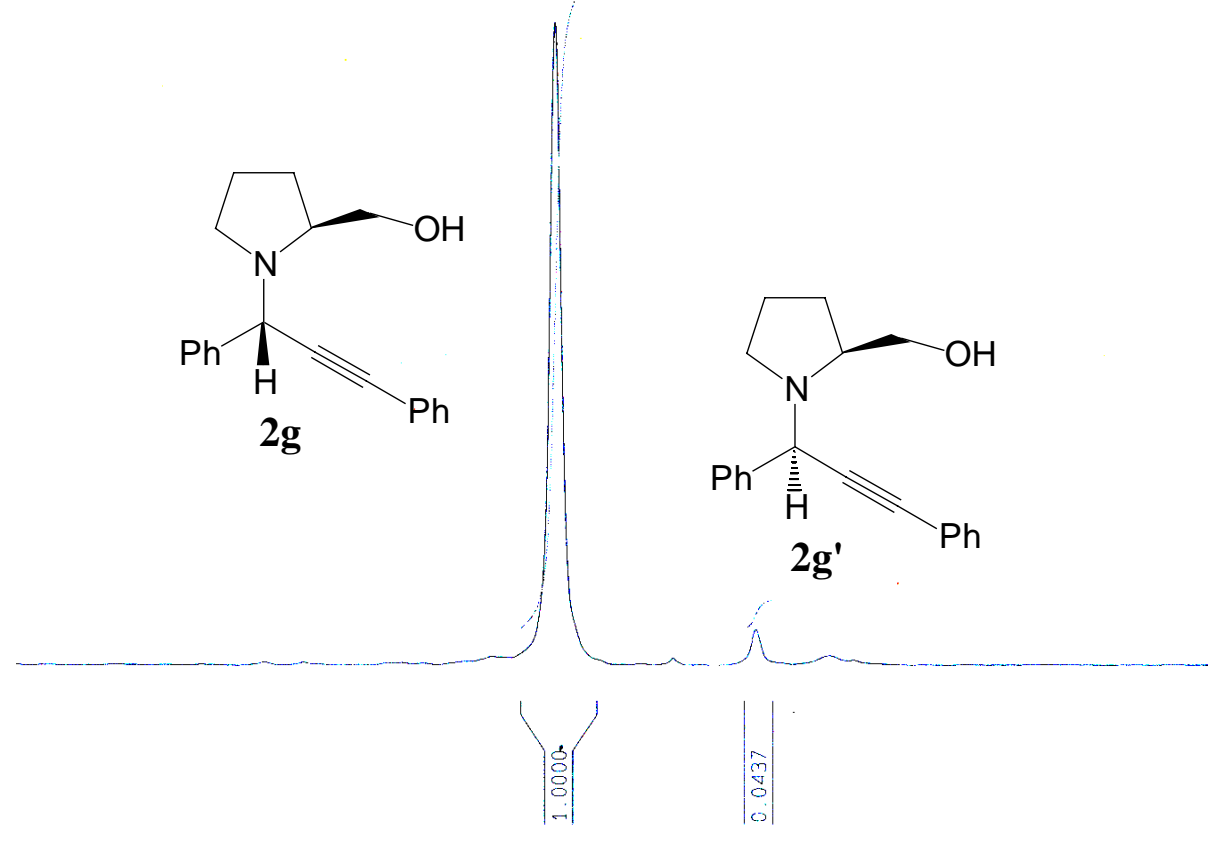

Table 2, entry 9
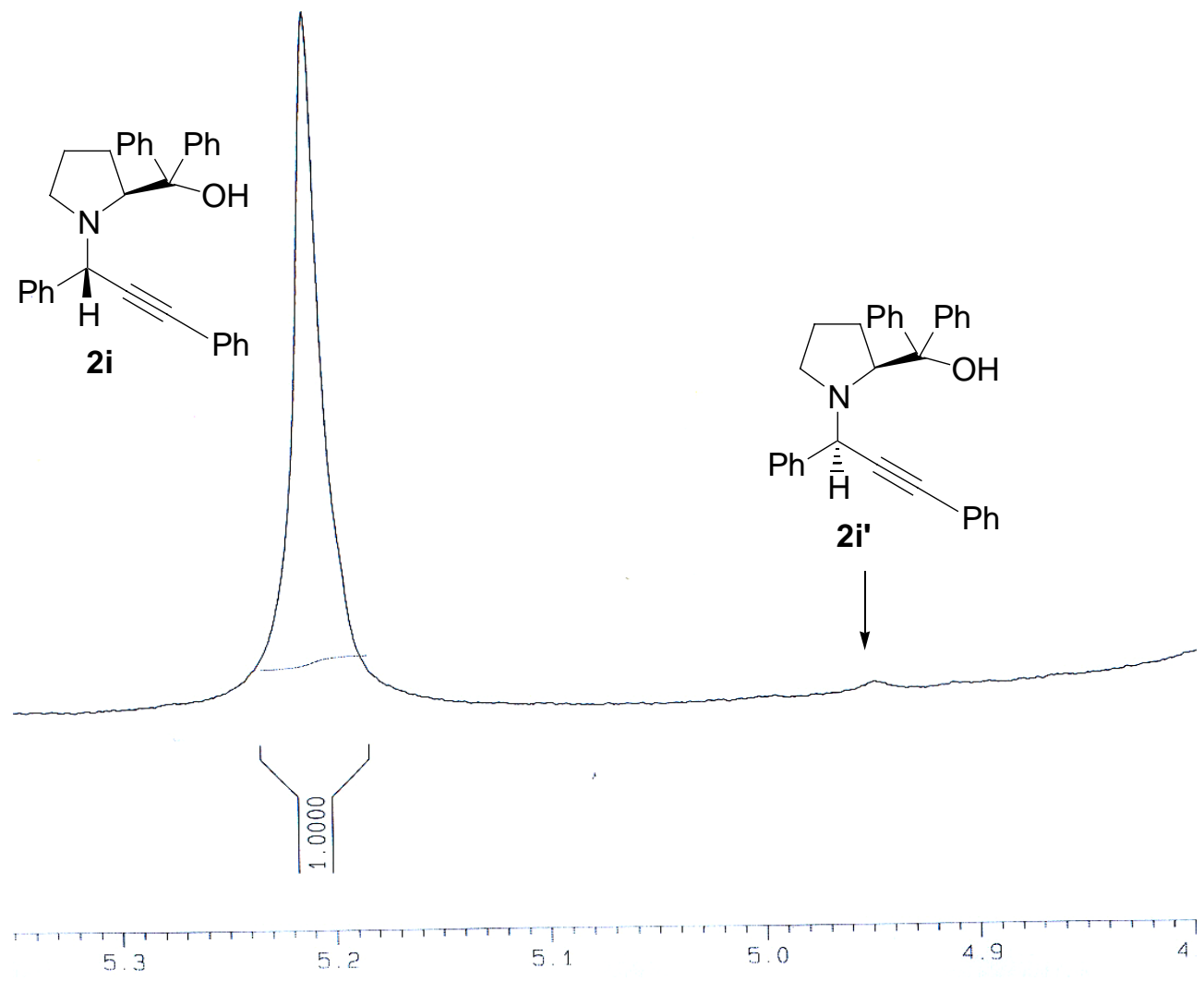


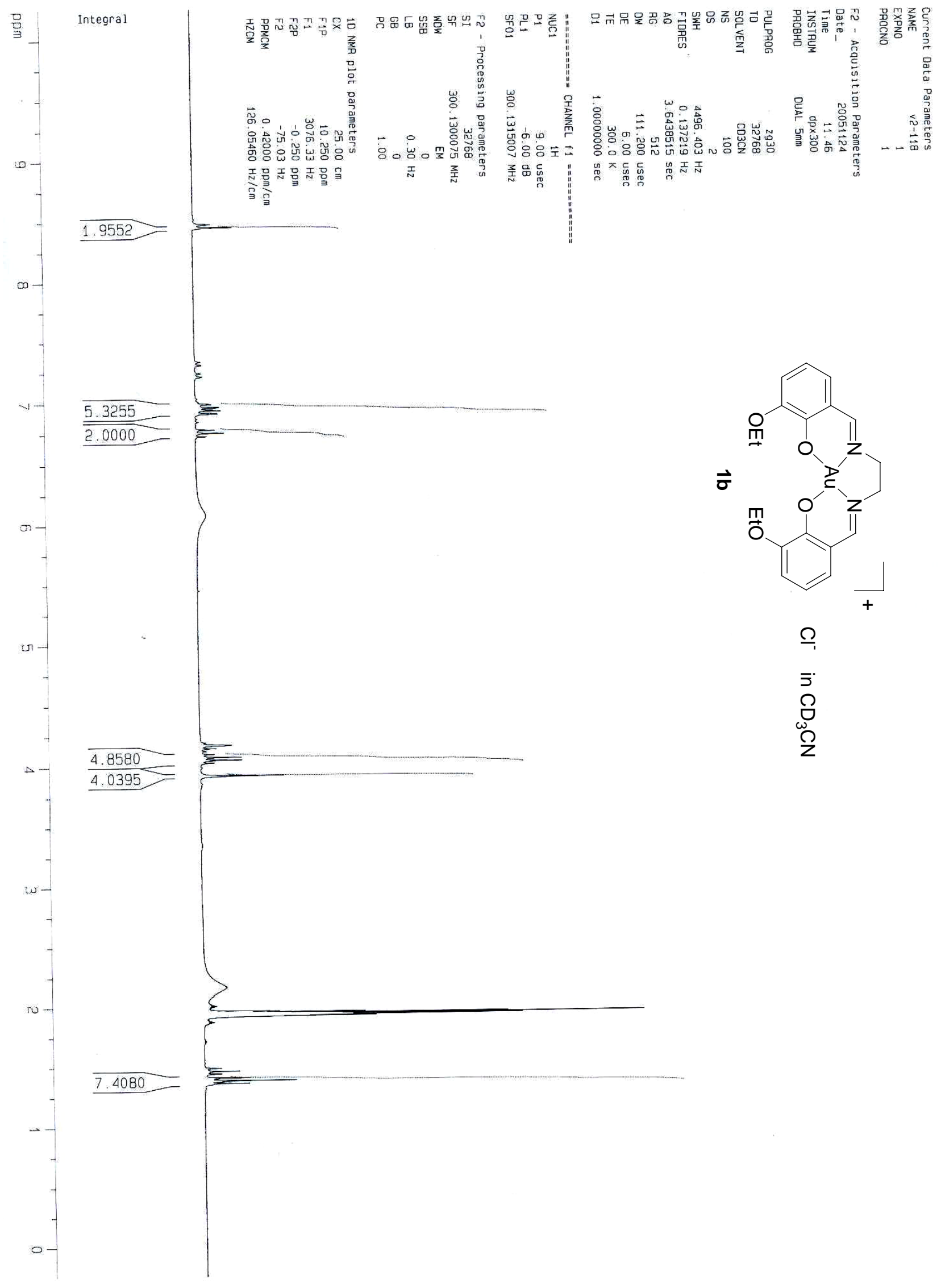




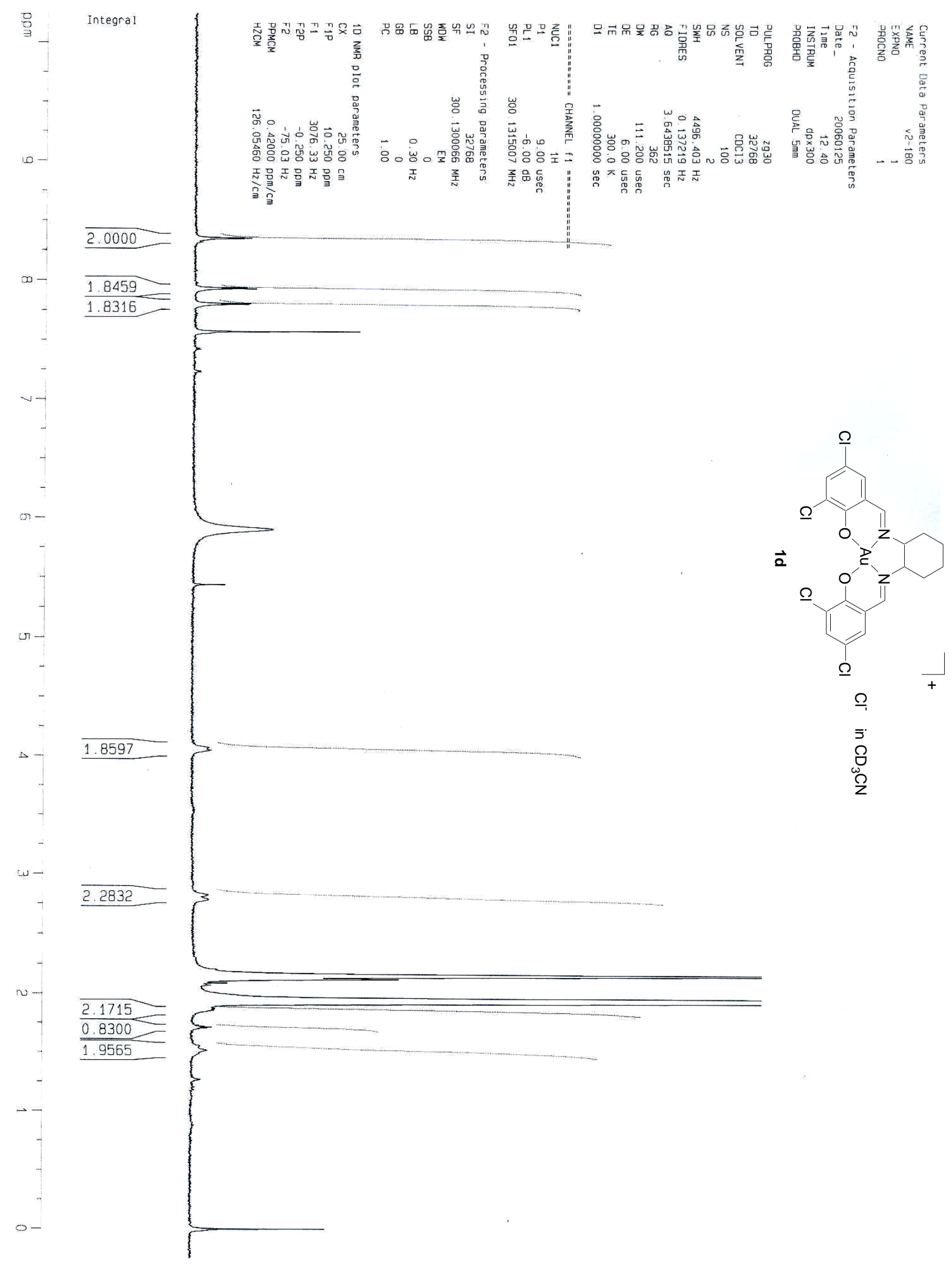




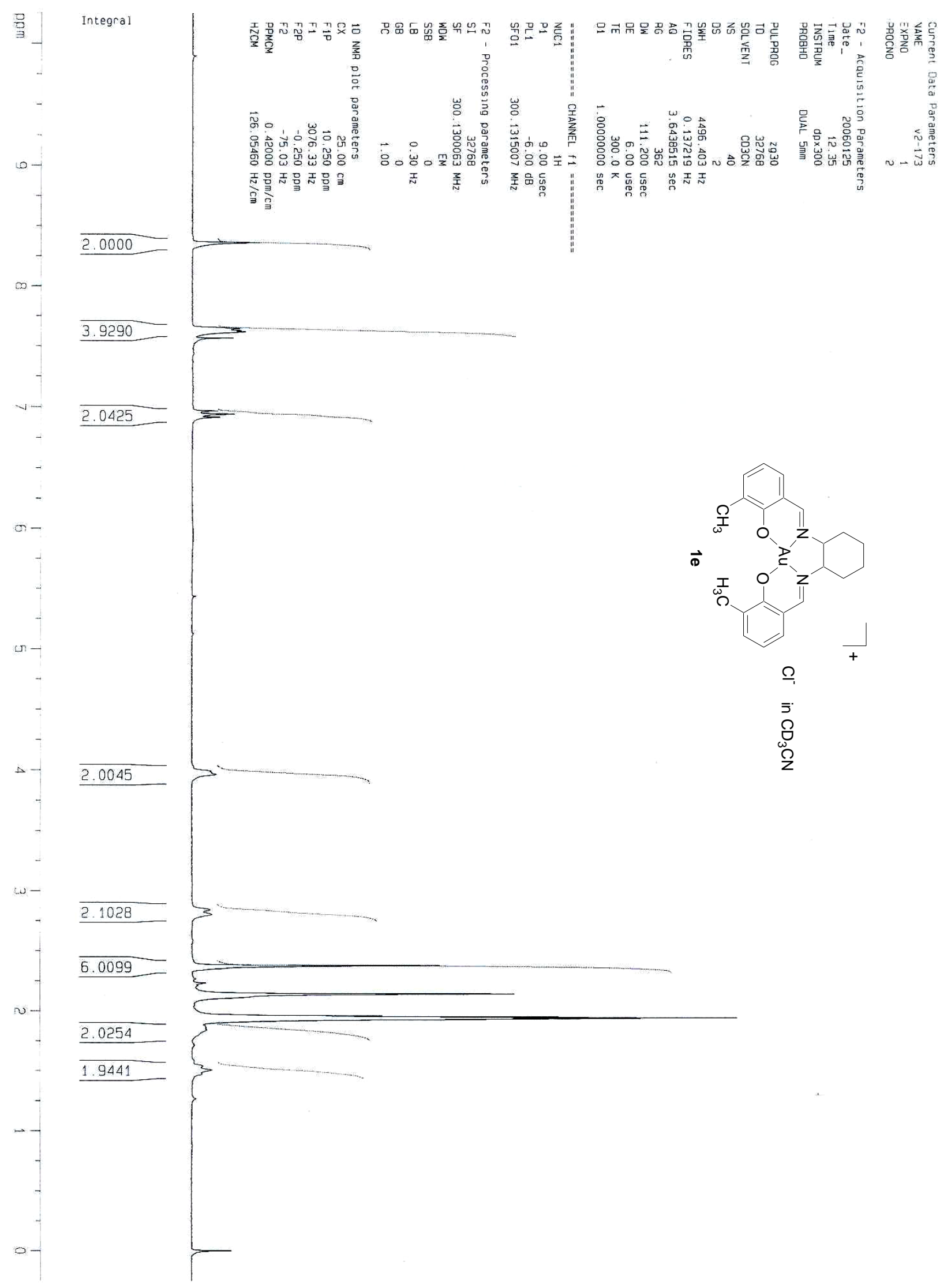




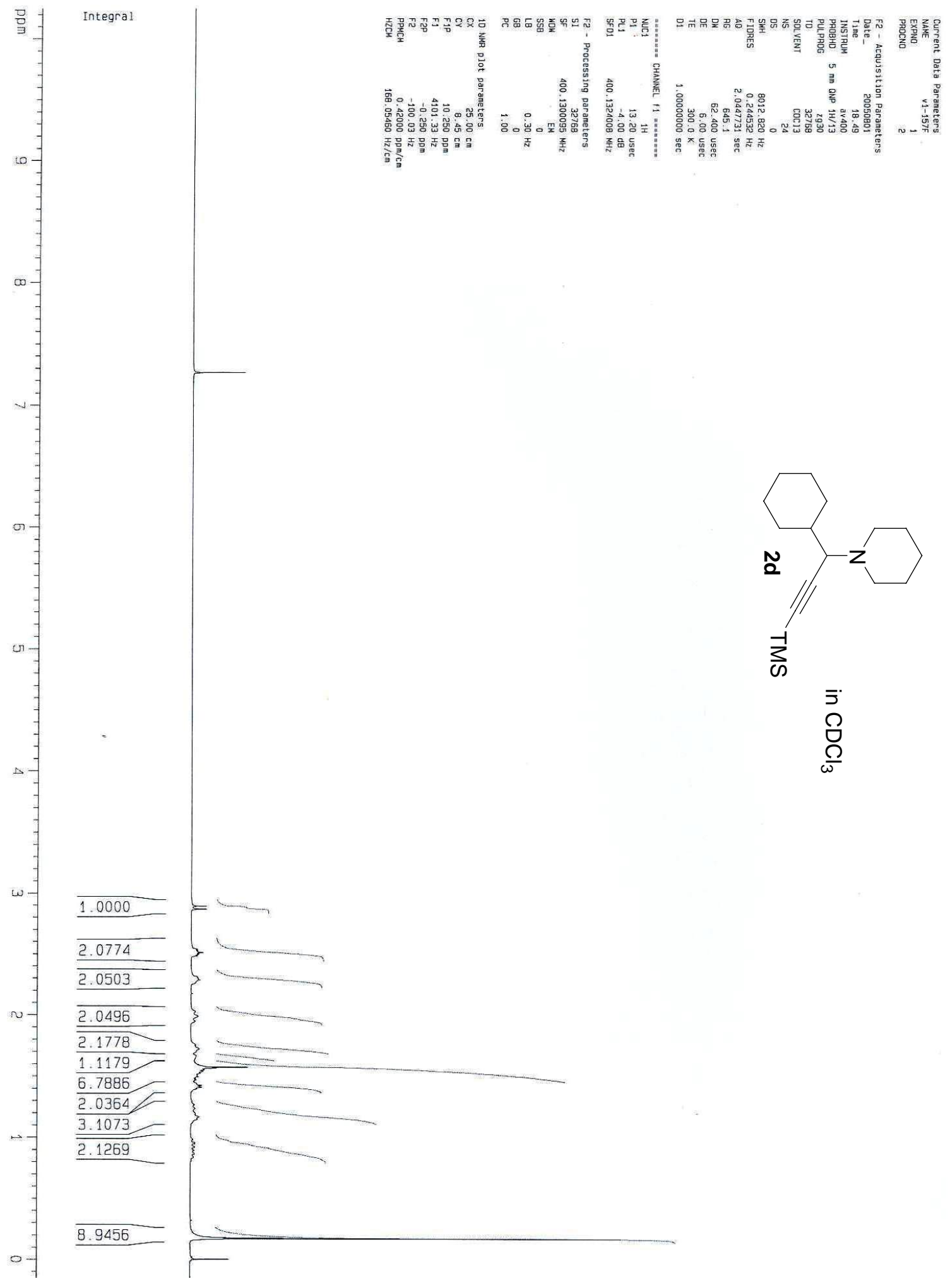




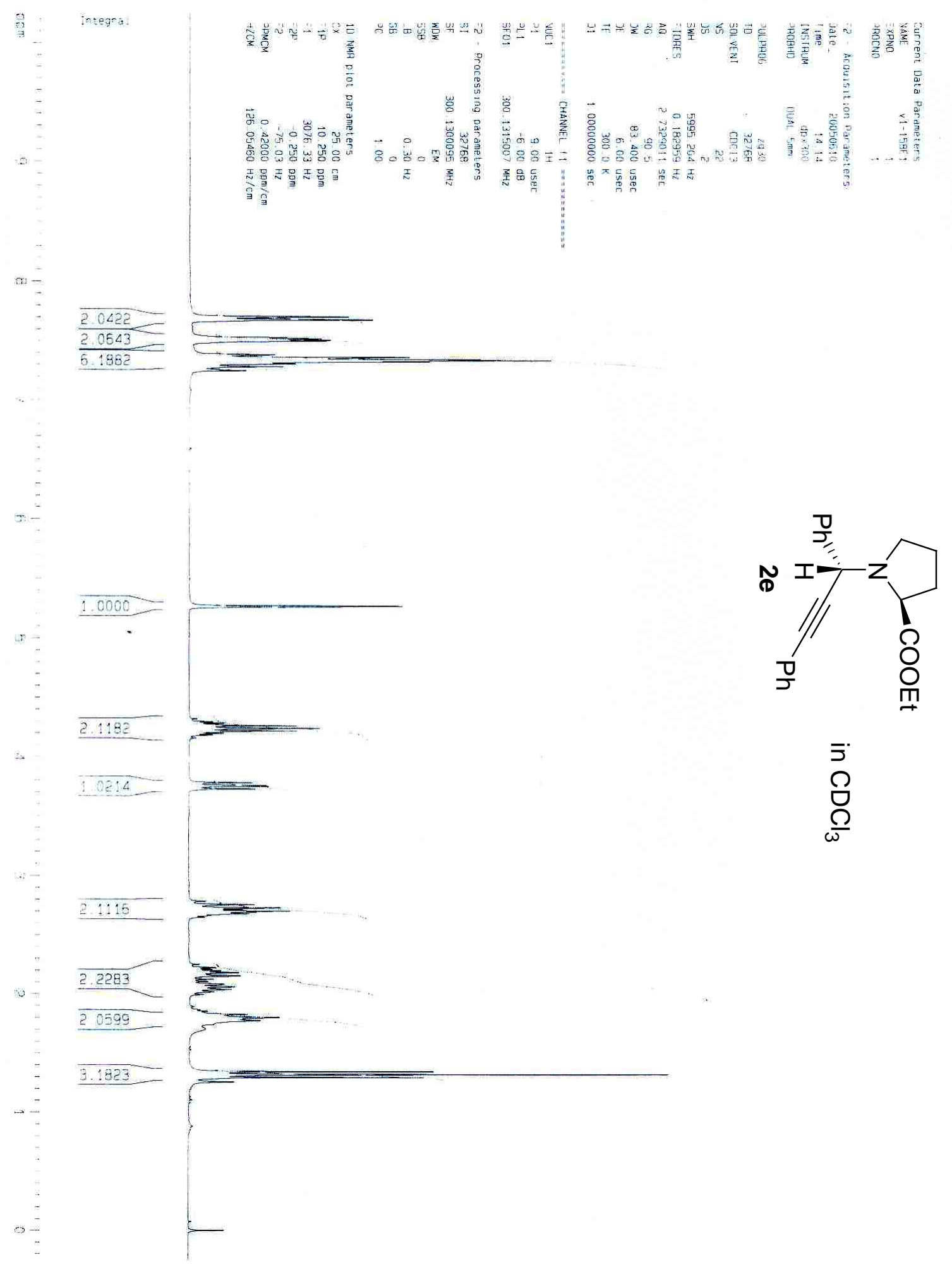




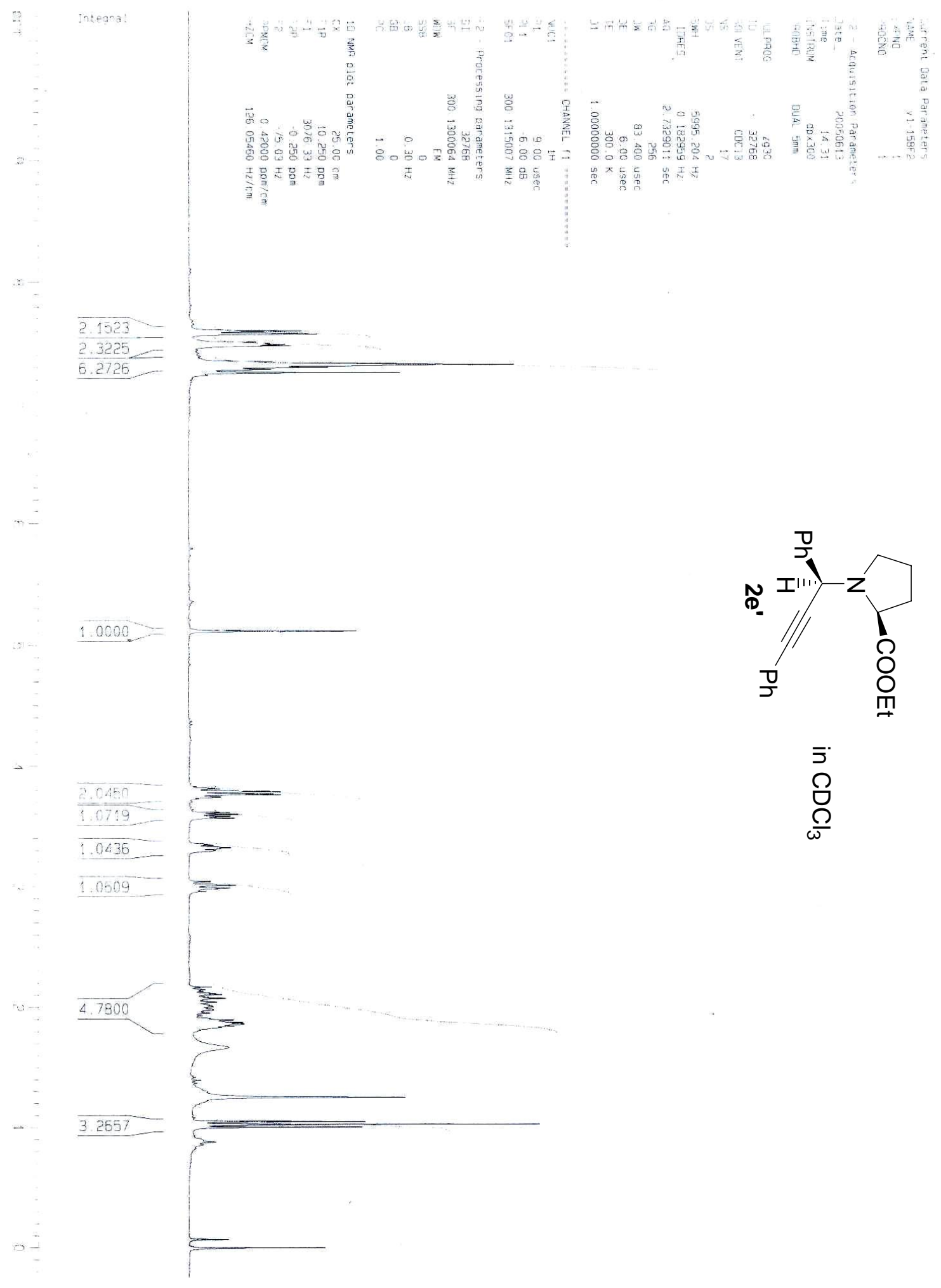




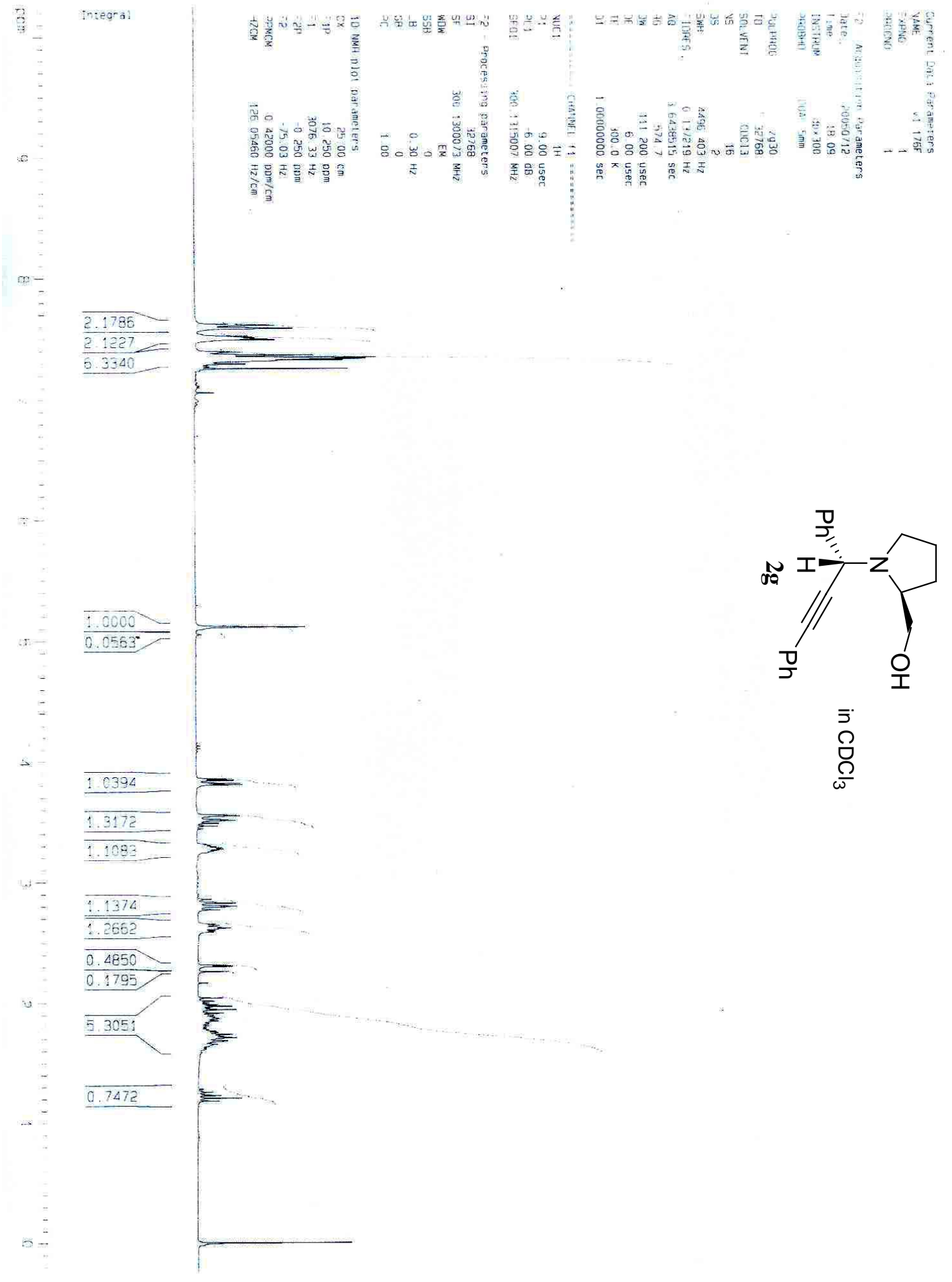




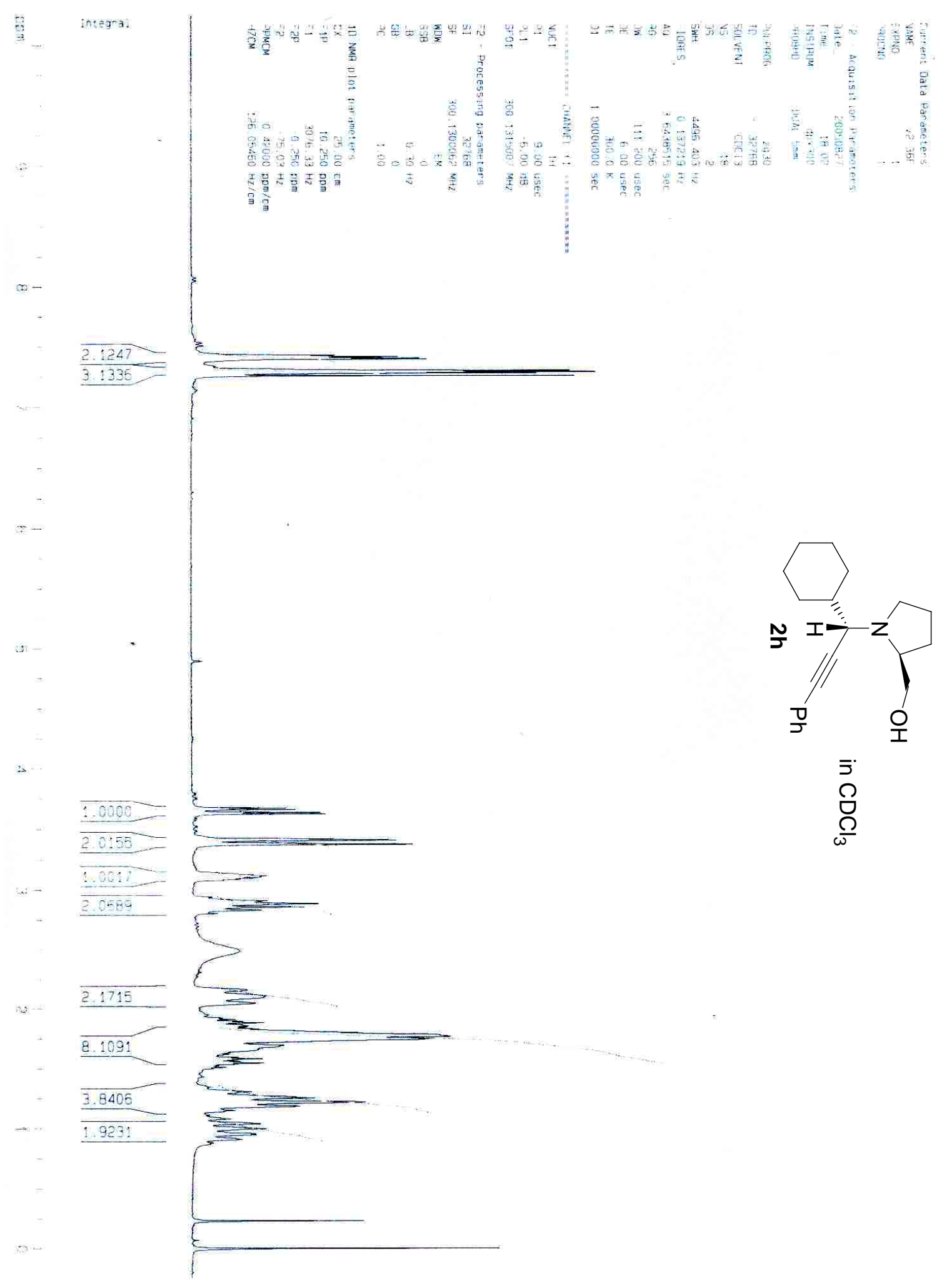




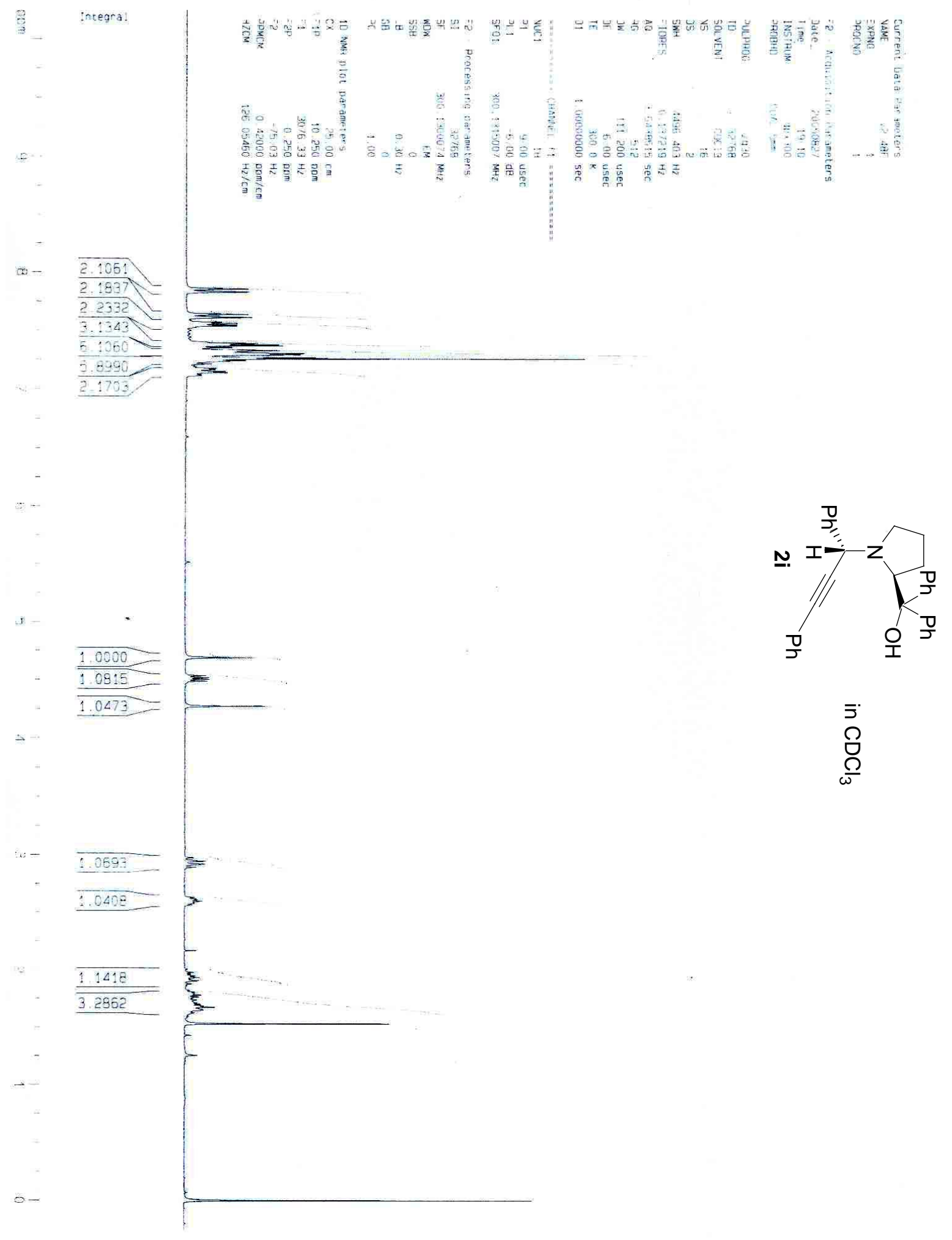




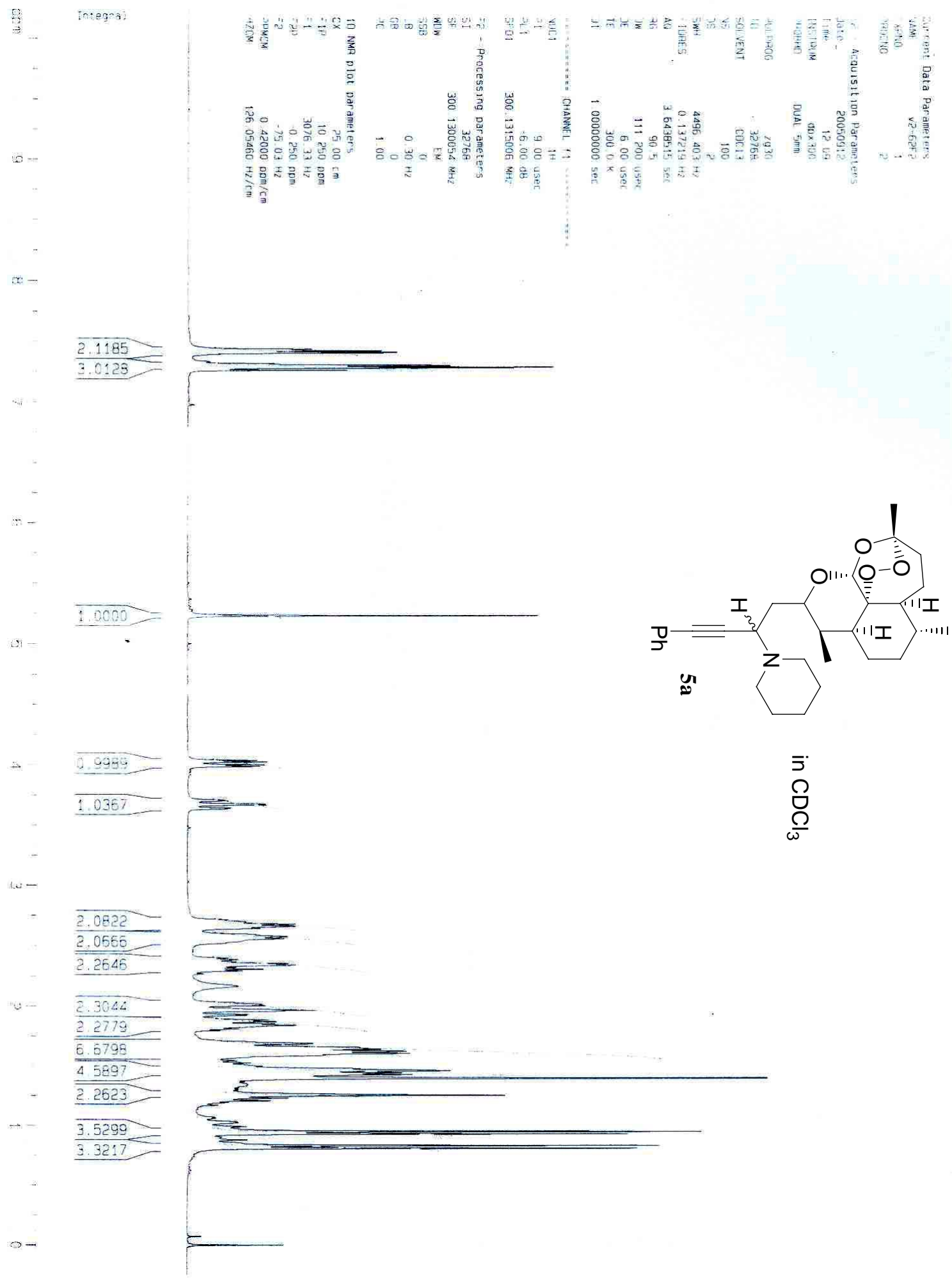




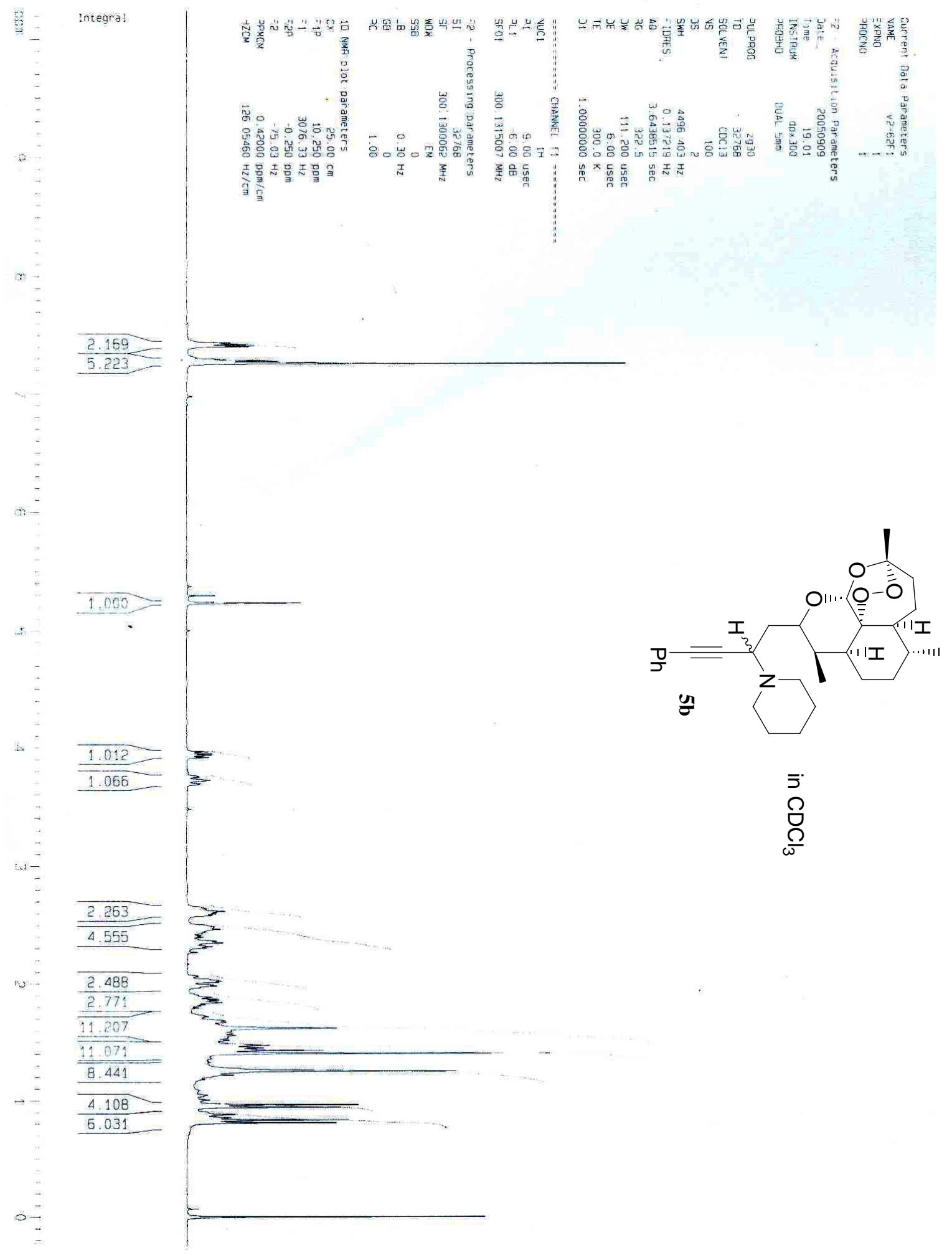




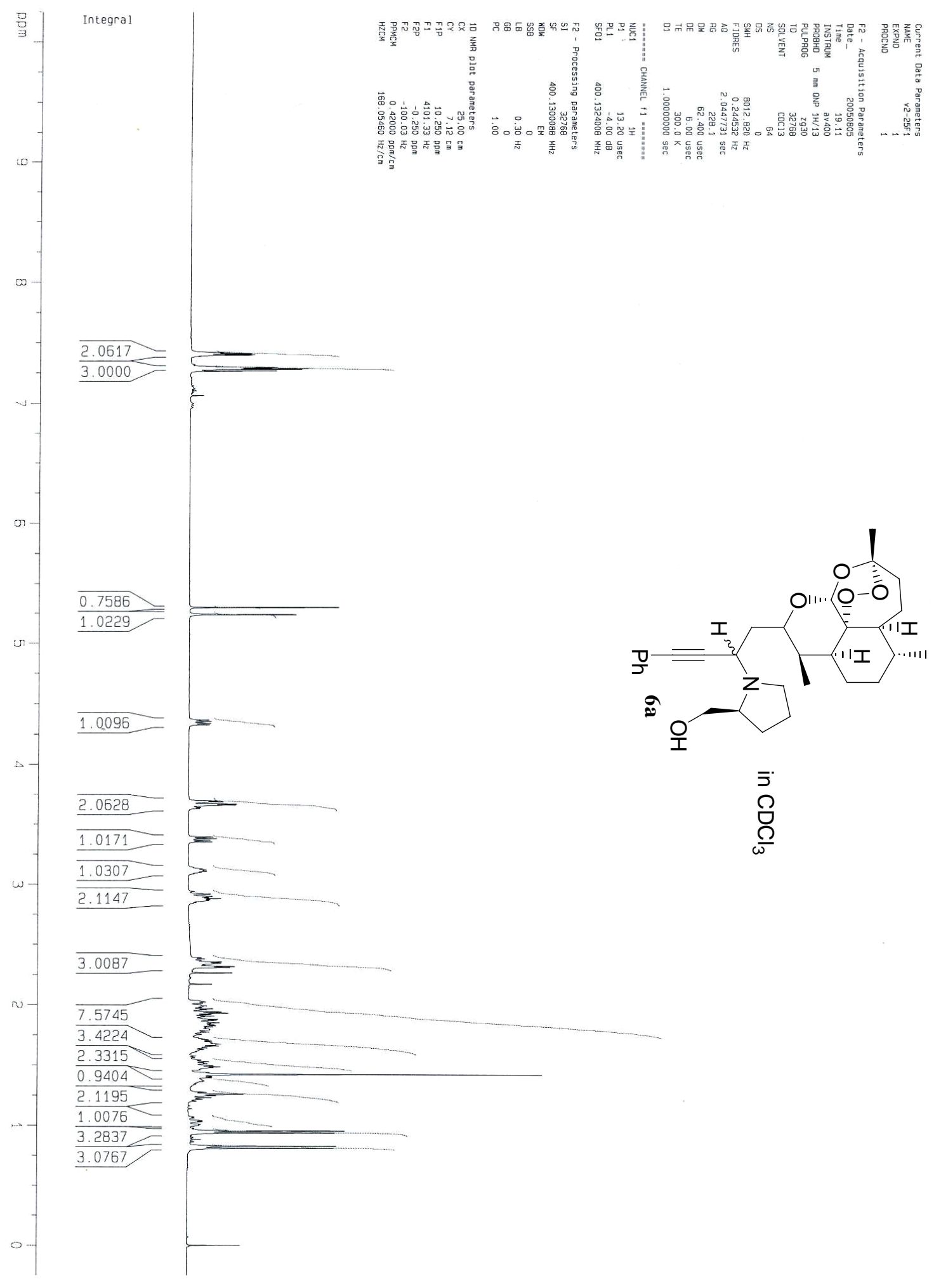




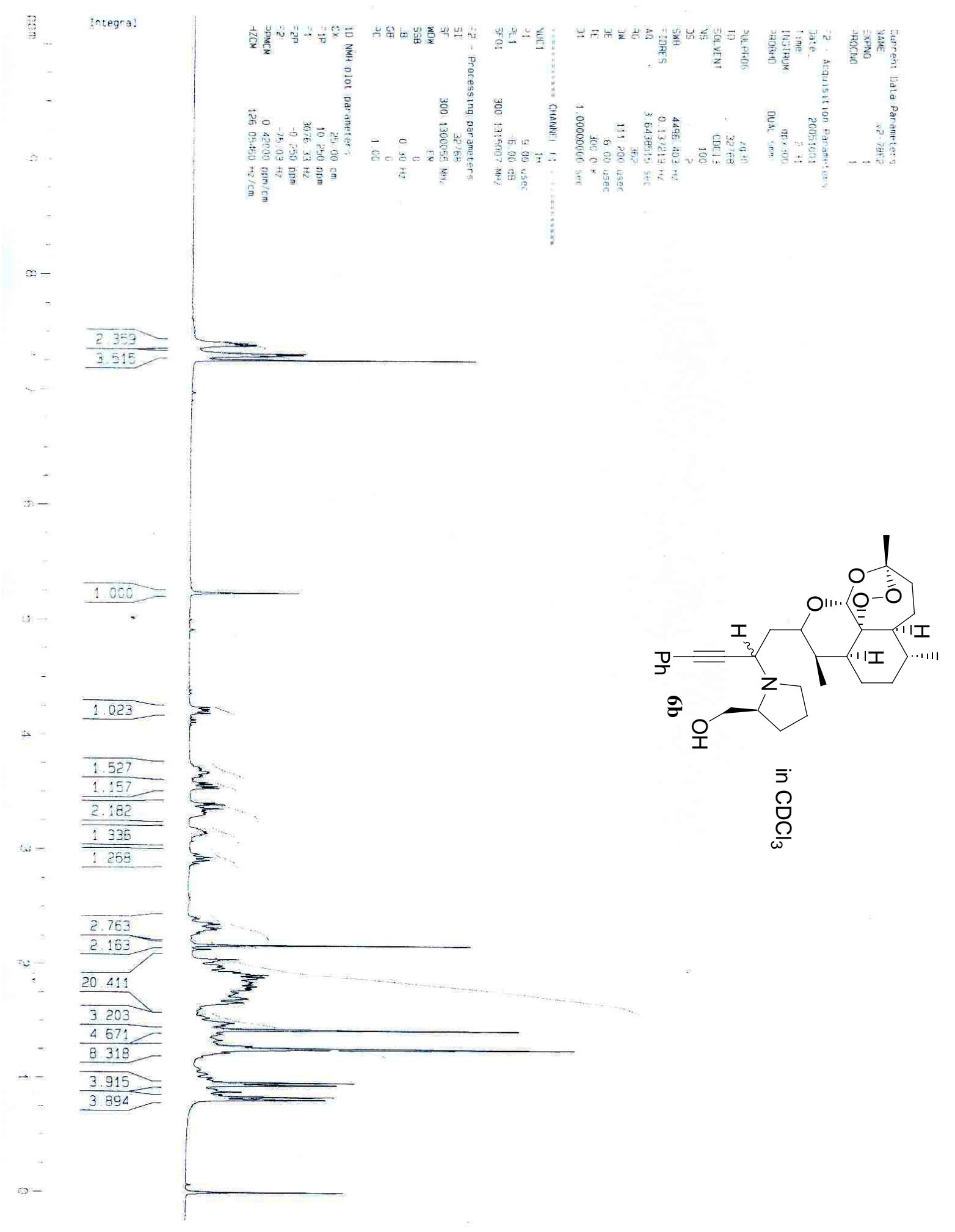




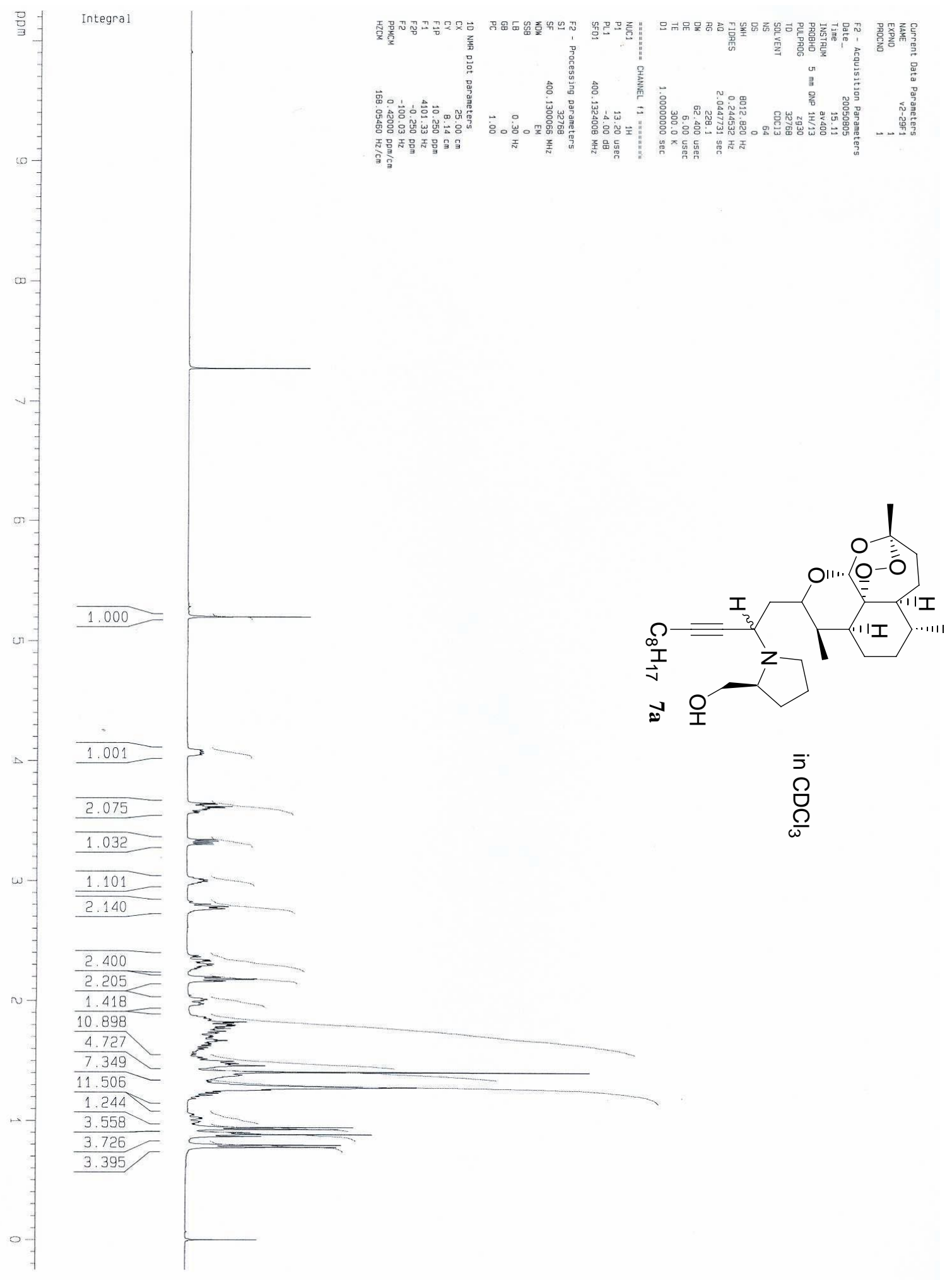




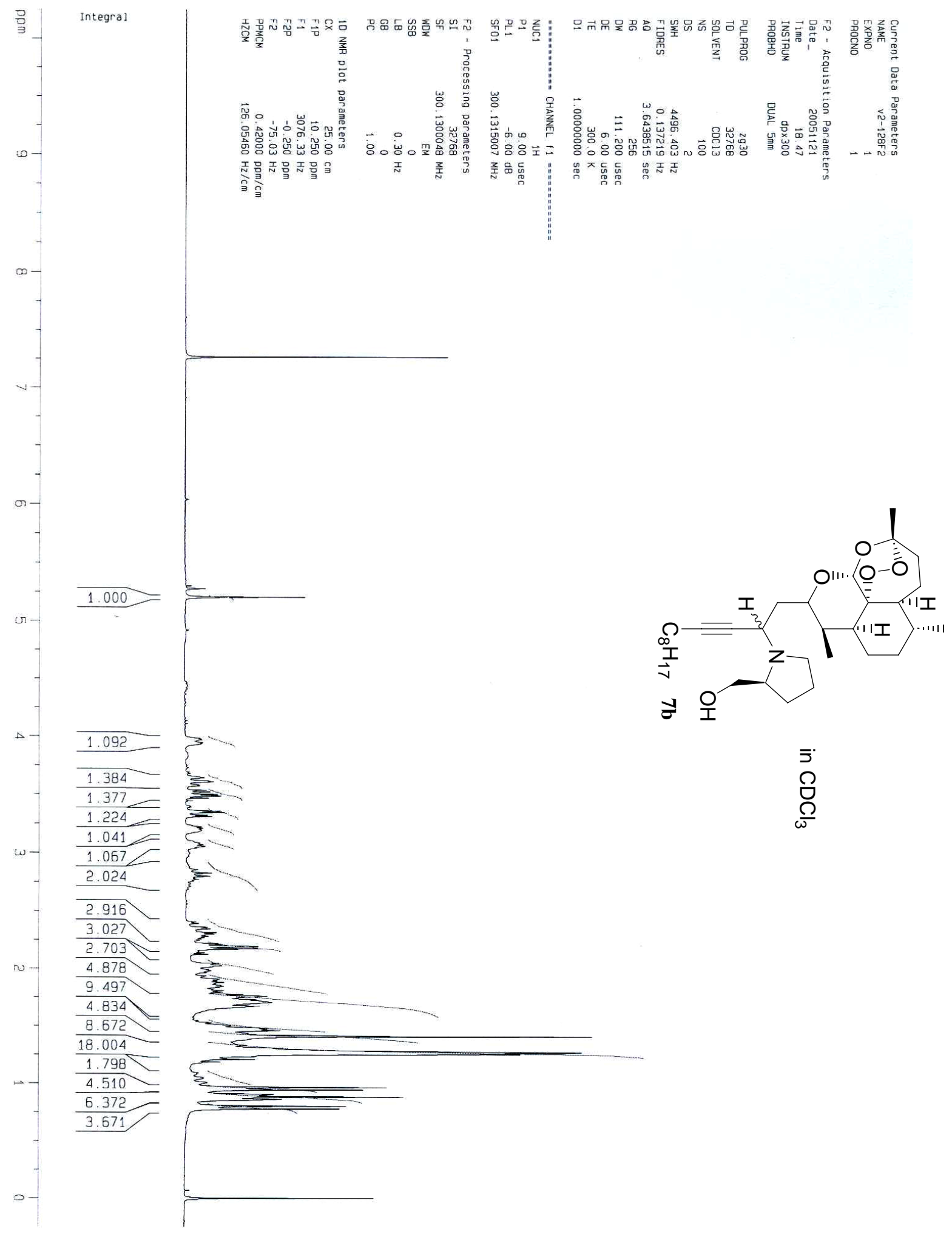




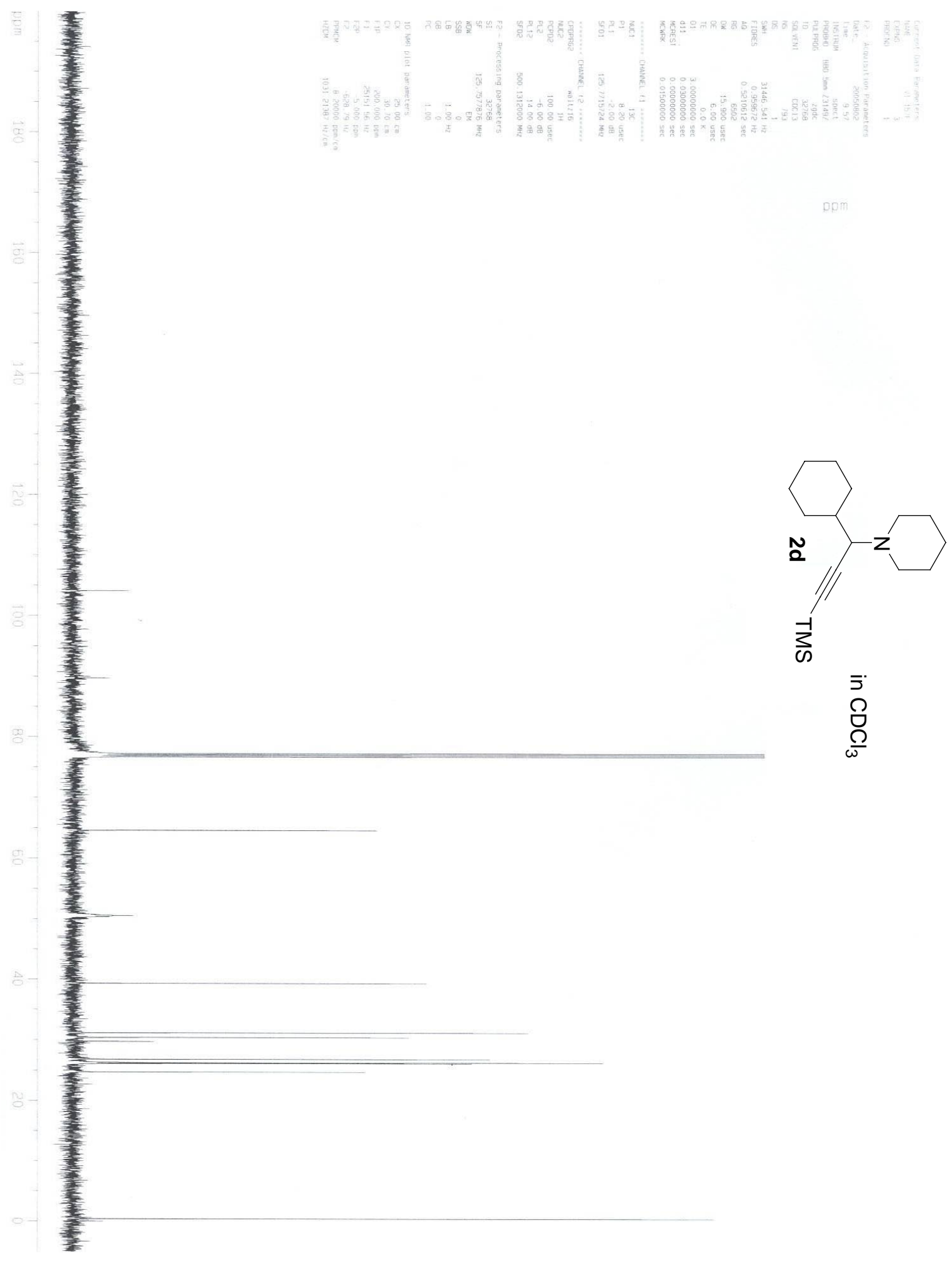




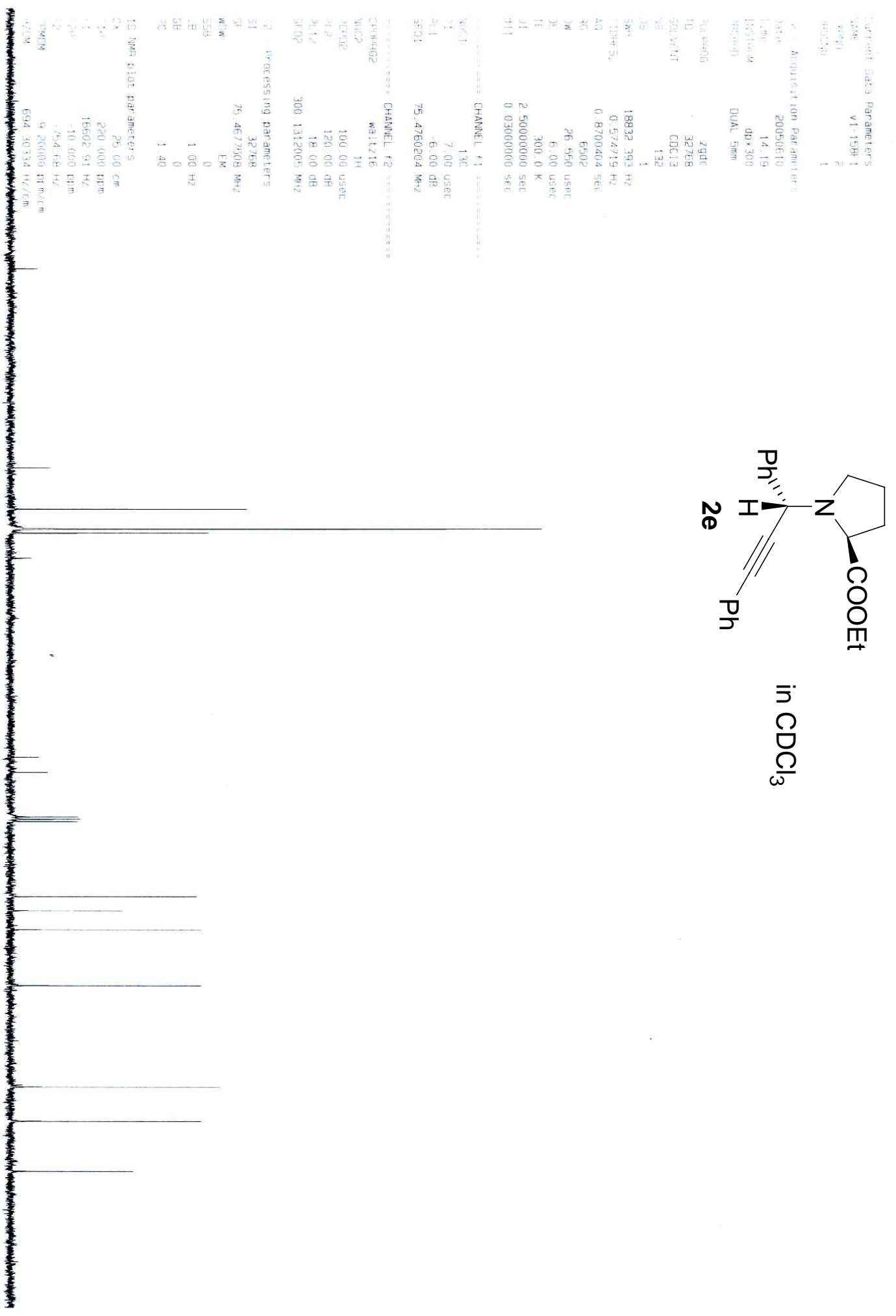




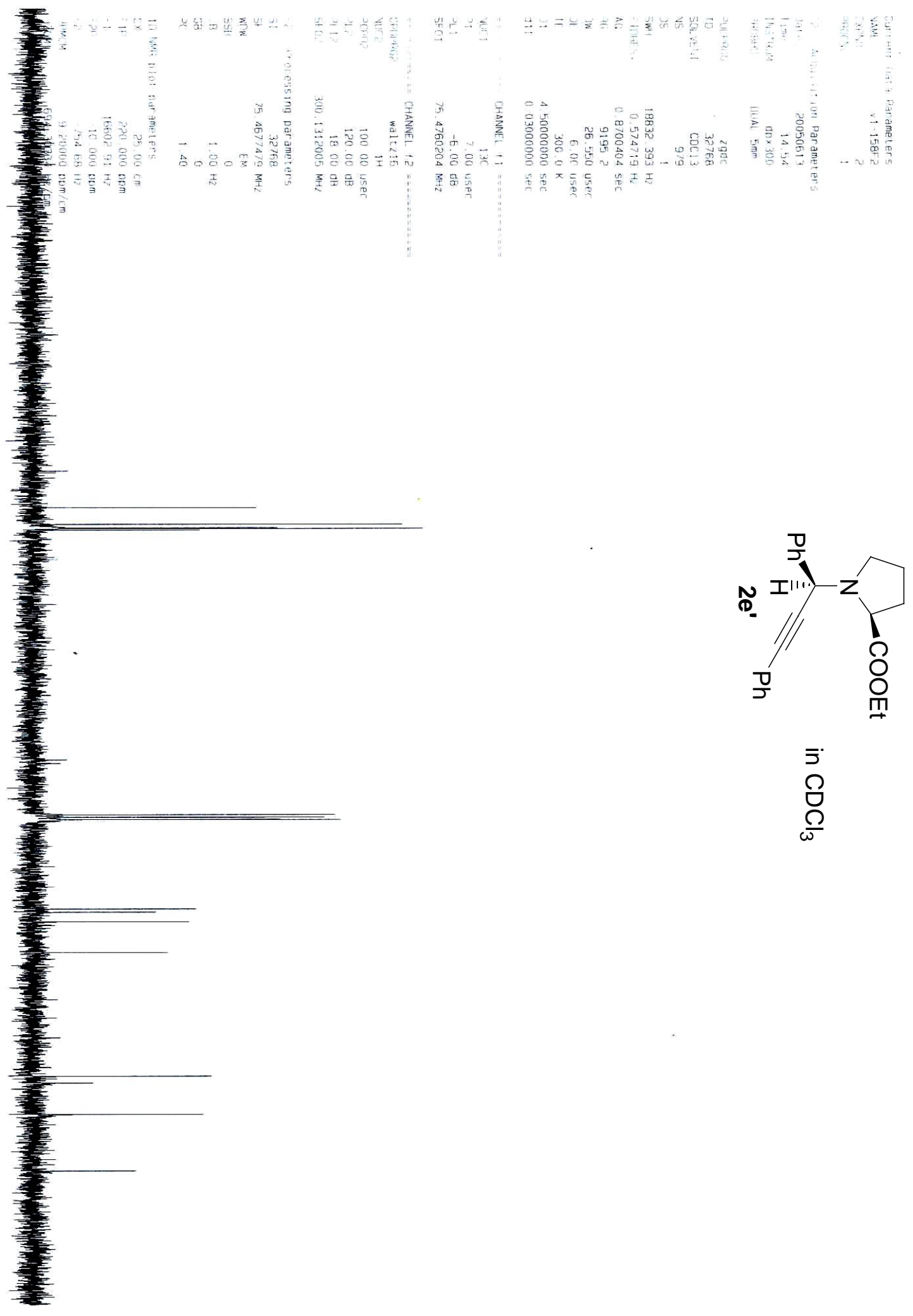




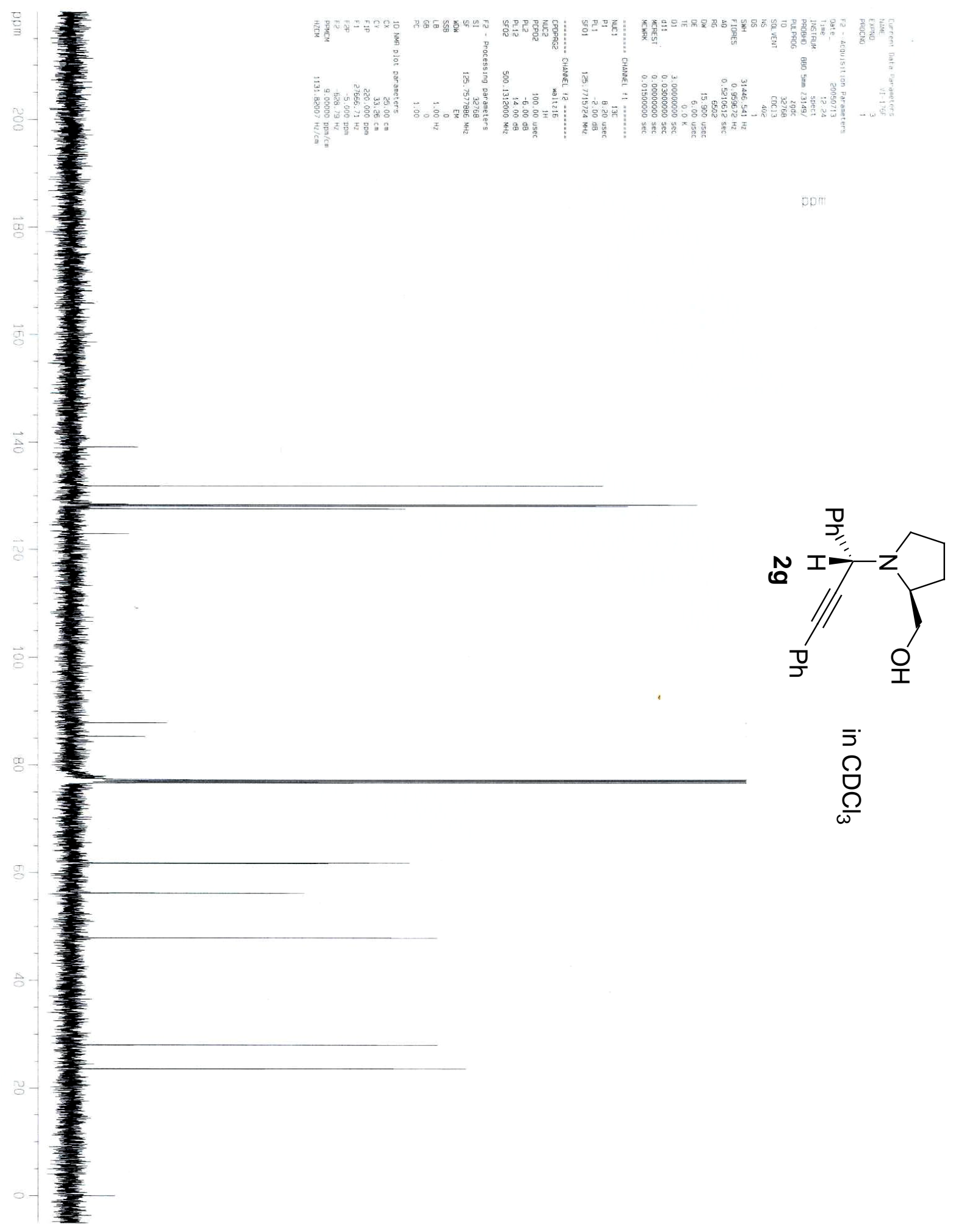




$$
\mid
$$




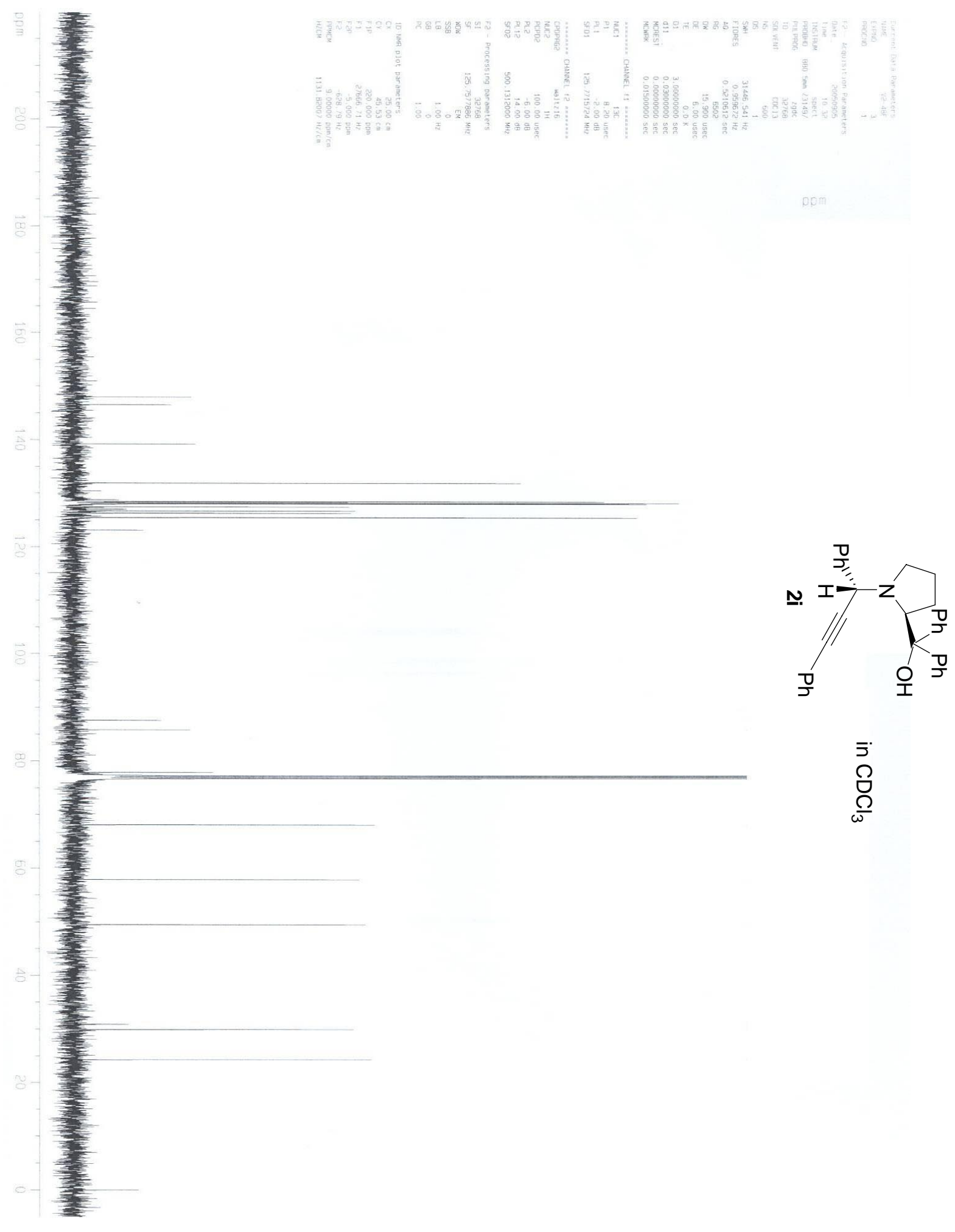




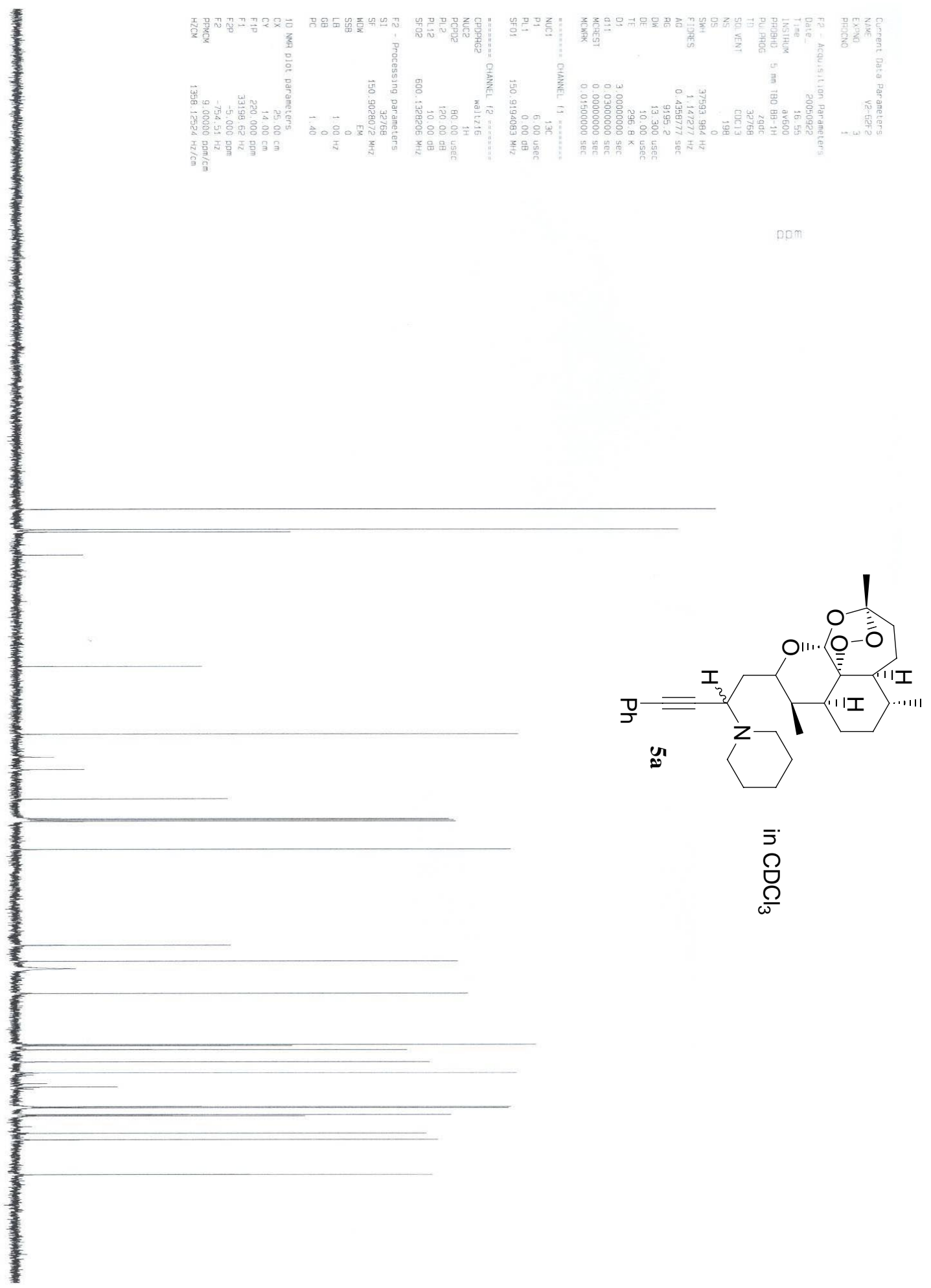




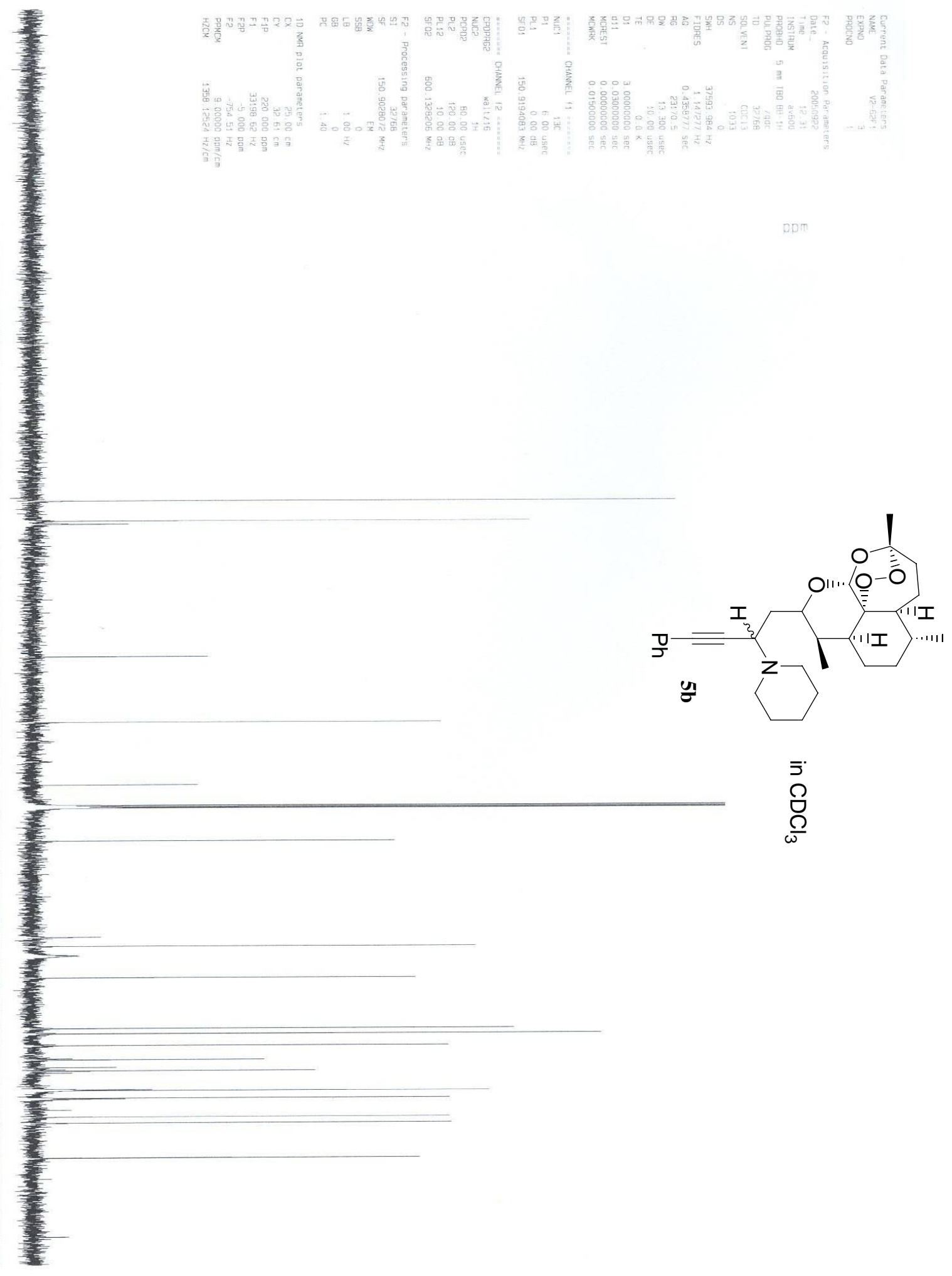



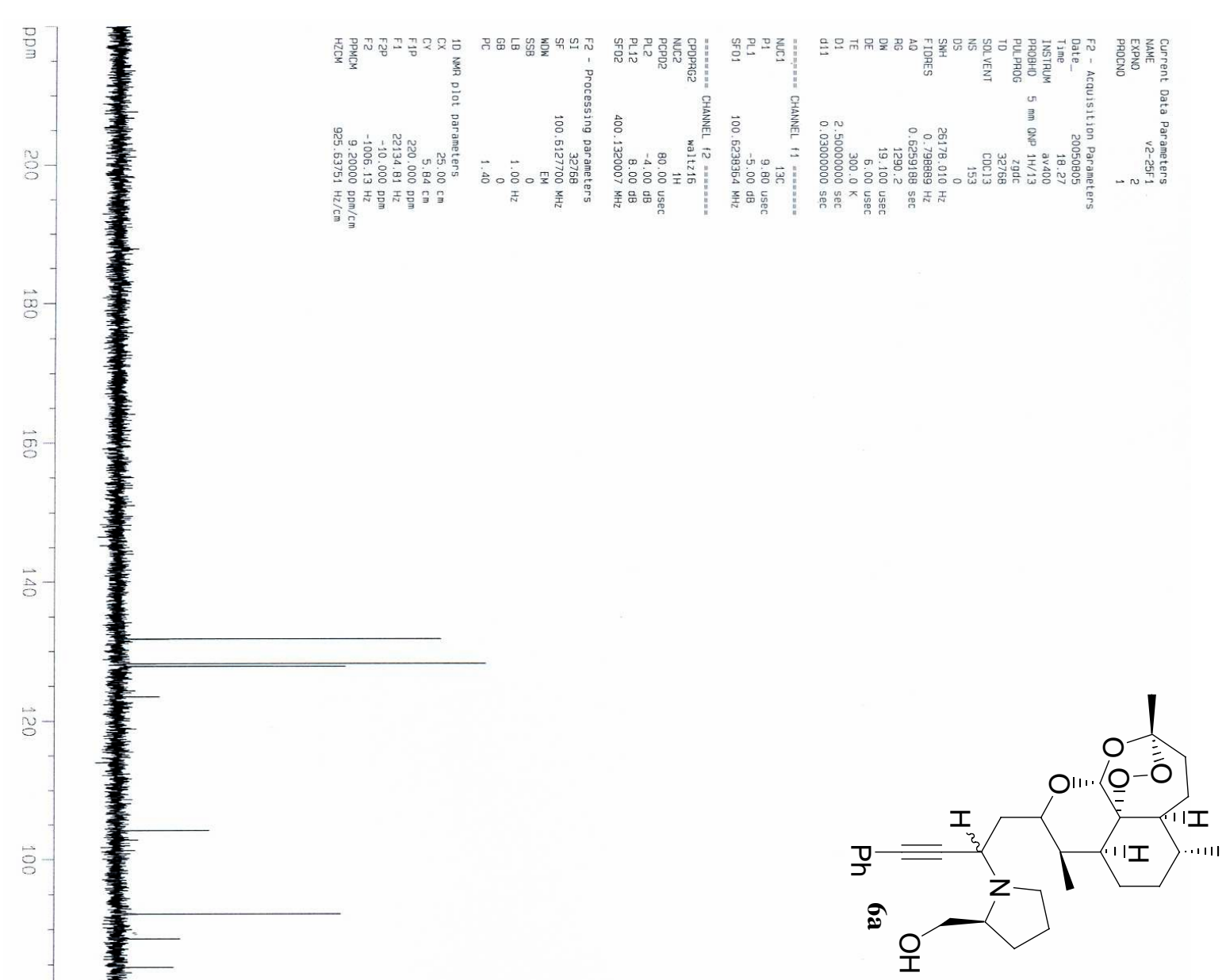

$\bar{J}$
$\rho$
$\frac{\Omega}{\omega}$ 


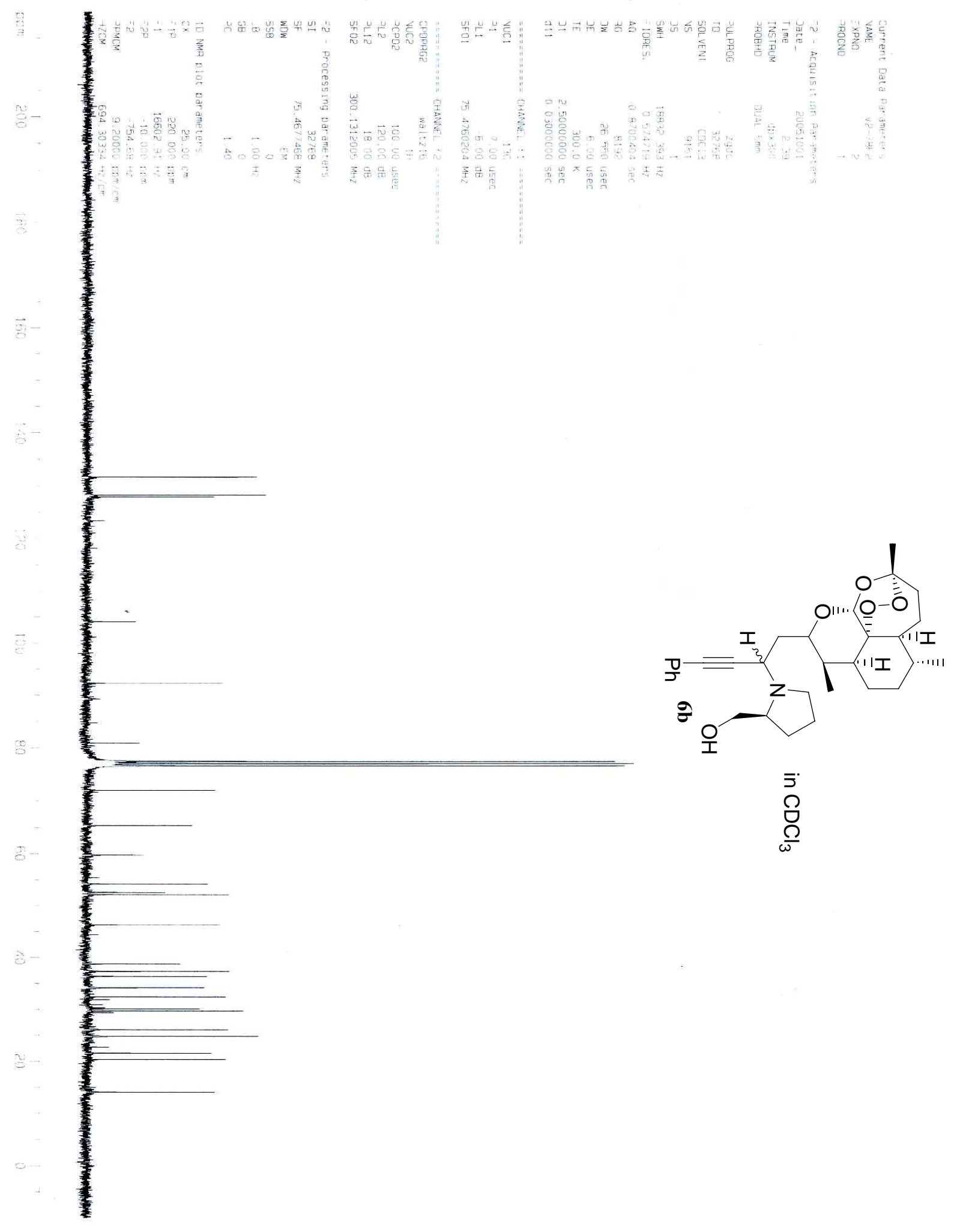




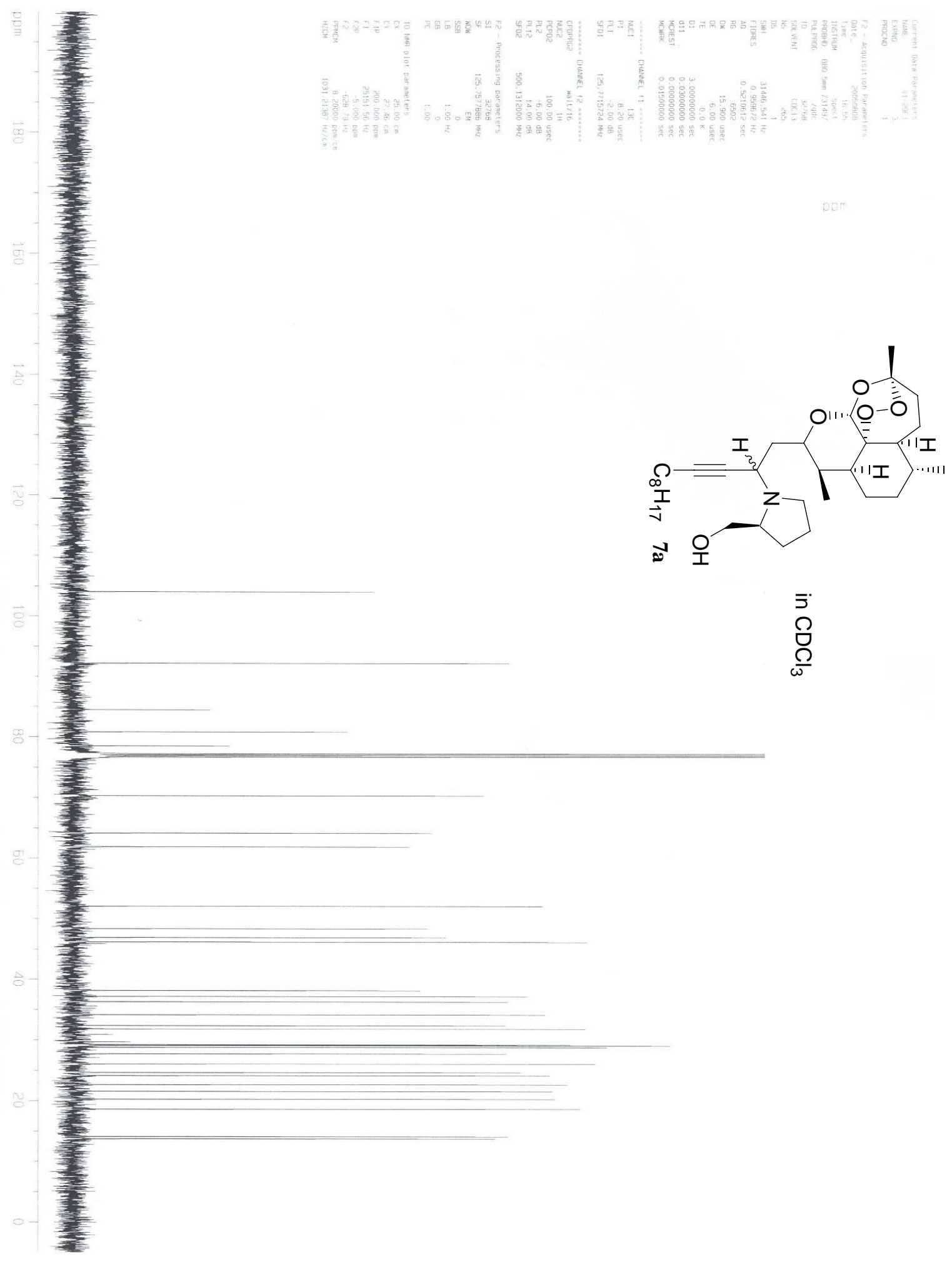



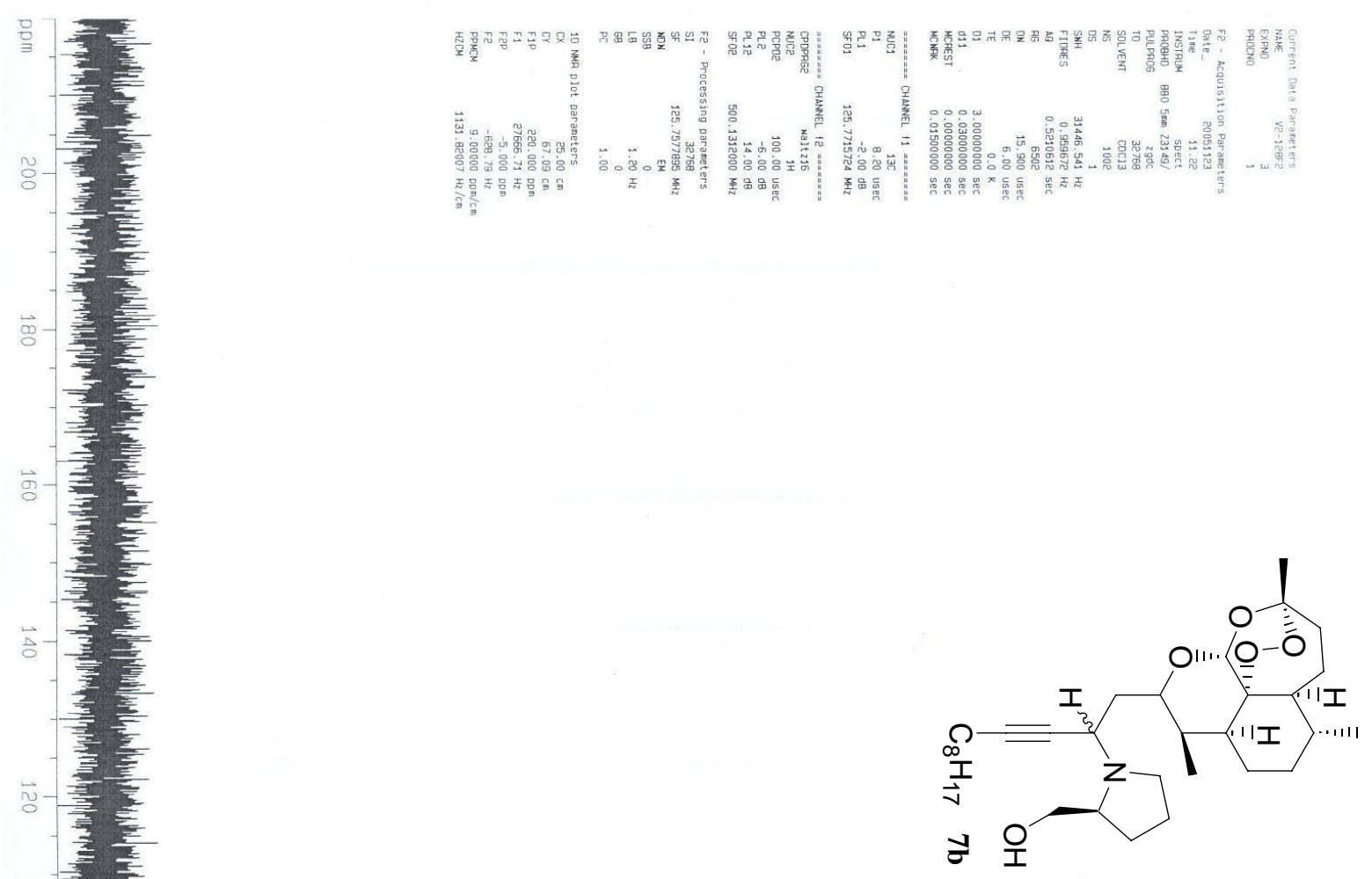

5
$\rho$
$\frac{\Omega}{\omega}$

\section{몽}

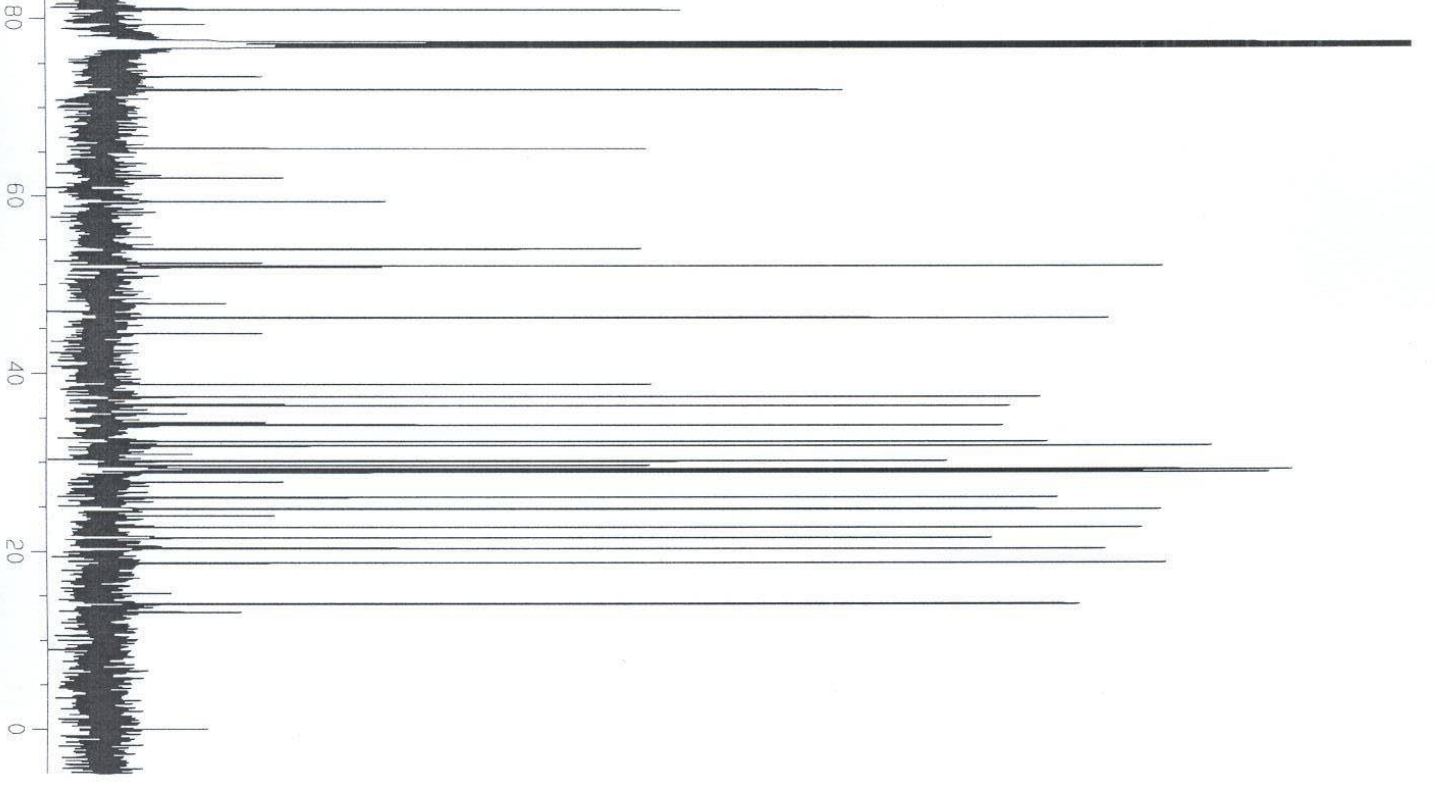

